\title{
1 Holocene-scale fire dynamics of central European temperate spruce-beech forests
}

2 5

Vachel A. Carter ${ }^{1 *}$, Alice Moravcová ${ }^{1}$, Richard C. Chiverrell ${ }^{2}$, Jennifer L. Clear ${ }^{3,4}$, Walter

Finsinger $^{5}$, Dagmar Dreslerová 6 , Karen Halsall², Petr Kuneš ${ }^{1}$

${ }^{1}$ Department of Botany, Faculty of Science, Charles University, Prague, Czech Republic

${ }^{2}$ Department of Geography and Planning, University of Liverpool, Liverpool, United Kingdom

${ }^{3}$ Department of Geography and Environmental Science, Liverpool Hope University, Liverpool, United Kingdom

${ }^{4}$ Department of Forest Ecology, Faculty of Forestry and Wood Science, Czech University of Life Science, Prague, Czech Republic

${ }^{5}$ Palaeoecology, ISEM (UMR 5554 CNRS/UM/EPHE), University of Montpellier, Place E. Bataillon, Montpellier, France

${ }^{6}$ Institute of Archaeology of the Czech Academy of Sciences, Prague, Czech Republic

Correspondence:

Dr. Vachel A. Carter

vachel.carter@gmail.com

Written for submission to Quaternary Science Reviews 


\section{Abstract}

This study investigated the long-term role and drivers of fire in the central European temperate spruce-beech forests from Prášilské jezero, Czech Republic. The results illustrate the complex relationship between broad-scale climate, vegetation composition, and local human activities on fire throughout the Holocene. Biomass burning was the highest (average 3 fires/1000 years) and most severe during the early Holocene when fire resistant taxa (Pinus, Corylus and Betula) dominated. Using a Generalized Additive Model to assess the response of dominant canopy taxa to changes in biomass burning and fire severity, response curves demonstrate a positive relationship $(p<0.01)$ between fire resistant taxa and increases in biomass burning. Norway spruce (Picea abies) established $\sim 10,000$ cal yr BP and expanded during peak biomass burning. Response curves show a slight negative relationship with Picea and increasing biomass burning, and a positive relationship with increasing fire severity. This suggests that central European spruce forests may not be significantly impacted by fire. Regional biomass burning dramatically decreased with the expansion of fire sensitive taxa (e.g. Fagus sylvatica) 6500 cal yr BP, yet no dramatic reduction in local fire frequency occurred. This suggests either human activities or rare fire-promoting climatic events were important in shaping local fire regimes. Fire activity peaked (6 fires/1000 years) 2500 cal yr BP and paralleled increases in anthropogenic pollen indicators. Fagus response curves illustrates a negative $(p<0.01)$ relationship with increasing biomass burning and fire severity suggesting that natural Fagus forests may be increasingly vulnerable to projected increases in wildfire occurrence.

\section{Keywords}

Climate; Fire; Holocene; Macrofossils; Paleoecology; Pollen; Sedimentary charcoal; 


\section{Highlights}

- First high-resolution fire-history record to discuss fire frequency from natural sprucebeech temperate forests in the Šumava Mountains, central Europe

- Fire has been an important disturbance agent in central Europe for the past 10,000 years

- Climate and vegetation were the primary drivers of fire in the early Holocene

- Humans activities were likely secondary drivers of fire throughout the Holocene

- Beech may be one of the most vulnerable species to projected increases in temperatures, heat stress, and risk of wildfires in central Europe.

\section{Introduction}

Fire is an important disturbance agent driving changes in vegetation composition, ecosystem structure and function, and nutrient cycling (Boerner, 1983; Bowman et al., 2009; Carcaillet et al., 2002; Whitlock et al., 2003). Paleoecological studies have documented the vital role of climate, vegetation, and human activities on global fire activity over millennia (Marlon et al., 2013; Power et al., 2008). Yet, knowledge gaps pertaining to the long-term role of fire in particular regions, specifically central Europe, still exist (Feurdean et al., 2012; Feurdean and Vannière, 2017). More important is the lack in understanding how forest canopy taxa will respond to changing fire regimes as a result of anthropogenically-induced climate change. Temperate forest fires in central Europe are often considered as a negligible ecosystem disturbance (Adámek et al., 2015) because of the assumed low flammability of deciduous forests (Ellenberg, 1982). Yet, over the past decade emerging literature has demonstrated that fires have occurred for millennia in central European forested ecosystems (e.g. Clark et al., 1989; Bobek et 
al. 2017; Niklasson et al., 2010; Novák et al. 2012). However, crucial parameters of fire regimes i.e. fire frequency and drivers of biomass burning, are neither fully understood nor discussed (Niklasson et al., 2010), specifically from central European Norway spruce (Picea abies) and European beech (Fagus sylvatica) forests.

Climate models predict more frequent and extreme climatic events such as heat-waves and droughts throughout Europe (Rajczak et al., 2013; Seneviratne et al. 2012), which can elevate fire risk and impact on vegetation (Camia et al., 2017; Lavelle et al., 2014; Linder et al., 2014). For instance, as a result of increasing temperature and drought, the susceptibility of mountain plant communities to mortality has increased (Allen et al., 2010). Because extreme climatic events also contribute to an increase in fire risk, composition and structure of particular plant communities may adapt to include more thermophilic species (Gottfried et al., 2012), thus favoring more fireprone ecosystems. As future projections suggest an increase in fire risk in central European ecosystems by the end of the $21^{\text {st }}$ century (Lung et al., 2013), it is important to understand longterm fire dynamics in order to determine how increasing wildfire activity may impact future temperate forests.

Fire activity is determined by both top-down (e.g. climate) and bottom-up (e.g. vegetation and human activities) drivers which combine to create different fire regimes across varying spatial and temporal scales. Climate variability is considered to be the dominant topdown driver of fire through its influence on broad-scale energy budgets and variations in moisture and temperature, which typically results in regional to continental-scale synchronization of fire activity (Falk et al., 2011). Local factors such as topography (i.e. slope and aspect) and fuel type (i.e. vegetation composition) typically create different mosaics of fire severities (Falk et al., 2011). However, human land use also significantly influences local fire 
regimes (Gill and Taylor, 2009), yet estimating the extent and magnitude of human-caused fires and land-use activities on natural fire regimes has proven to be difficult (see Kaplan et al., 2016). Because top-down and bottom-up factors vary spatially and temporally (Courtney-Mustaphi et al., 2013; Gavin et al., 2003; Gedalof, 2011), long-term fire histories are necessary in order to investigate the relationship between drivers of fire and their influence on local fire regimes (Whitlock et al., 2010).

As the role of fire in central European temperate forests is often deemed unimportant, there is a clear lack of understanding in: i) the relative importance and role of fire in these forests, and ii) the relationship between the dominant forest canopy taxa and changing fire regimes (i.e. changes in biomass burning and fire severities). To fill these gaps, we present a 11,500-year high-resolution paleoecological reconstruction of vegetation dynamics and fire history from lacustrine sediments obtained from Prášilské jezero (Šumava Mountains, Czech Republic). This record explores for the first time drivers of fire dynamics in these primary temperate spruce-beech forests. The main objectives are to: 1) identify the key drivers of Holocene fire regimes; and 2) assess the response of the dominant forest canopy to changes in biomass burning and fire severities.

\section{Study area}

Prášilské jezero (49 04' 30.684” N, 1323'59.136” E, 1079 m a.s.1.) (Fig. 1) is located within the unmanaged portion of Šumava National Park within a relatively steep glacial cirque, which deglaciated $\sim 14,000$ years ago (Mentlík et al., 2010). Tree-covered flanks extend 200-300 $\mathrm{m}$ above the lake. It is a small oligotrophic lake (3.7 ha) with a relatively large (52 ha) catchment, and a catchment area to lake volume ratio of 1.93 (Vrba et al., 1996, 2000). The 
catchment bedrock is composed of metamorphic crystalline rocks with gneiss, migmatite, and quartzite with local areas of granite (Mentlík et al., 2010; Pelc and Šebesta, 1994).

The surrounding vegetation is dominated by Norway spruce with minor components of European beech, rowan (Sorbus aucuparia L.), silver birch (Betula pendula Roth), sycamore maple (Acer pseudoplatanus L.), and silver fir (Abies alba Mill.). The understory is dominated by common mountainous spruce forest vegetation such as grasses (Avenella flexuosa L., Calamagrostis villosa J.F. Gmel., Luzula sylvatica Huds.), herbs (Prenanthes purpurea L., Senecio ovatus Willd., Soldanella montana Willd., Trientalis europaea L.), and small shrubs (Rubus idaeus L., Vaccinium myrtillus L., V. vitis-idaea L.). Sedges and shade-tolerant species (Carex canescens L., C. echinata Murray, Juncus effusus L., J. filiformis L., Oxalis acetosella L.) occur in shady and mesic areas along the inflowing stream, Jezerní potok. Ferns (Athyrium distentifolium Tausch ex Opiz, Blechnum spicant L., Dryopteris dilatata Hoffm.) and ground pine (Lycopodium annotinum L.) are also common in the understory vegetation.

Based on $>50$-year long meteorological data (Czech Hydrometeorological Institute) from the closest weather station, Churáňov (Fig. 1), the modern Šumava region is characterized as a semi-humid continental climate with wet and cold winters, and wet and mild summers with an interpolated mean annual temperature and precipitation of $4.5^{\circ} \mathrm{C}$ and $941 \mathrm{~mm}$ year-1. 


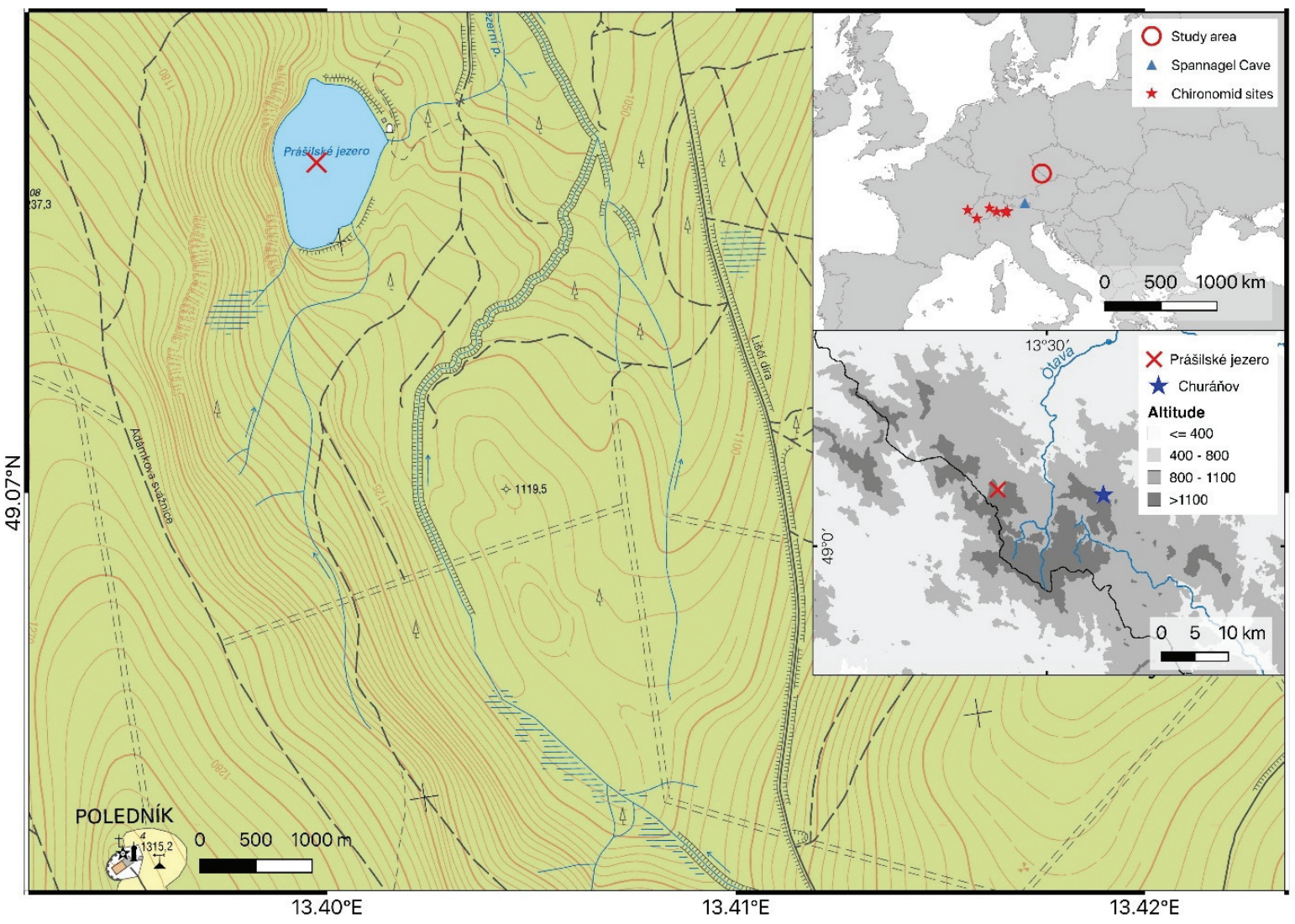

Fig. 1. Site map of Prášilské jezero (red ' $x$ ') located in the Šumava Mountains of south-western

Czech Republic (red circle). The red stars (Heiri et al., 2015) and blue triangle (Fohlmeister et al., 2013) show the localities used to reconstruct central European Holocene-climate.

Meteorological data from Churáňov weather station (blue star), located approximately $20 \mathrm{~km}$ from Prášilské jezero, were used in this study to create a local macrophysical climate model (Bryson, 2005).

3. Methods

\subsection{Core retrieval, sediment limnology and radiocarbon dating}


146 from the deepest $(14.8 \mathrm{~m})$ part of Prášilské jezero from a floating platform. The sediment-water

147 interface was collected using a gravity corer (Boyle, 1995), and the longer profiles with a

148 Russian corer $(1.5 \times 0.075 \mathrm{~m})$. Sediments were taken back to the University of Liverpool where 149 they were subsampled at high-resolution (contiguous $0.5 \mathrm{~cm}$ intervals). Samples were then 150 shipped to Charles University where the paleoecological analyses were conducted. 1978) (Table SI1). Age-depth relationships were modelled in a Bayesian framework using 'BACON' (Blaaw and Christen, 2011) using the ${ }^{210} \mathrm{~Pb}$ and ${ }^{14} \mathrm{C}$ dates. $\mathrm{All}{ }^{14} \mathrm{C}$ dates were calibrated with the IntCal13 dataset (Reimer et al., 2013), and a Student- $t$ distribution was used to account for scatter in the ${ }^{14} \mathrm{C}$ measurements, and for statistical outliers (Blaauw and Christen, 2011). The weighted mean modelled ages against depth were smoothed using a 21-point moving average (Fig. 2), and used to calculate sediment, pollen, and charcoal accumulation rates. 
159

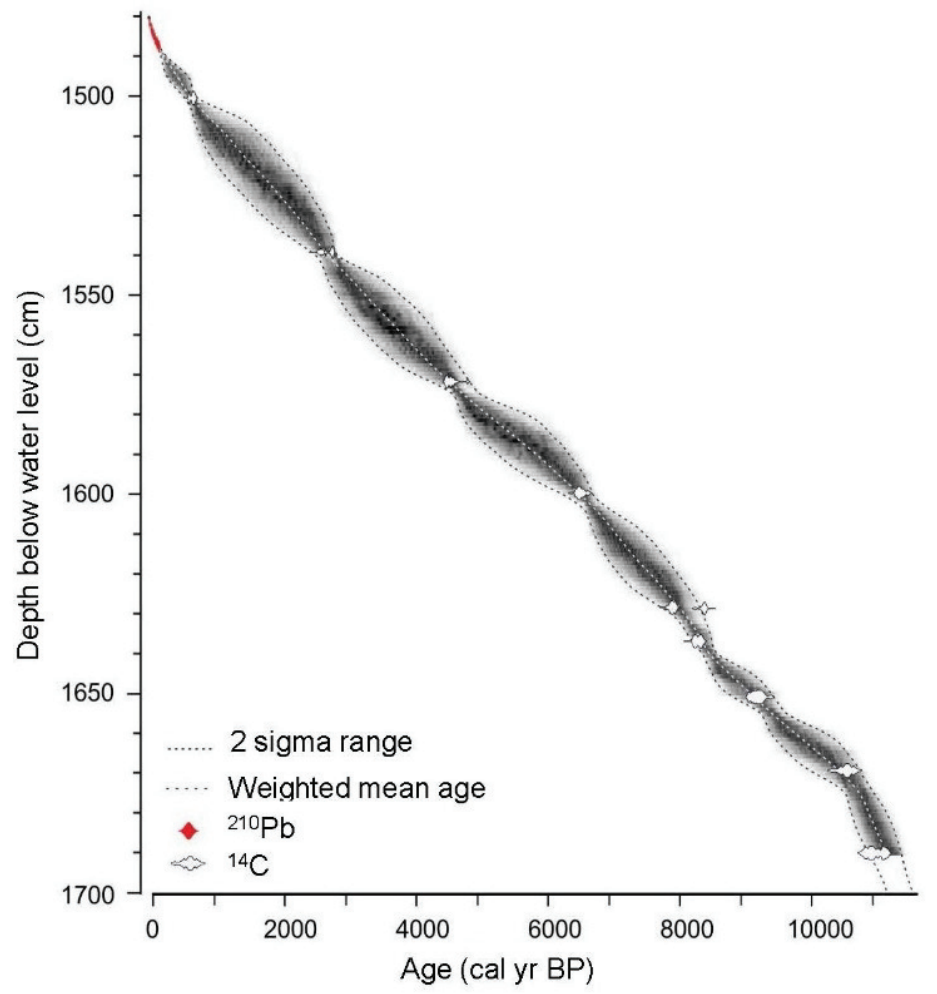

Fig. 2. Age-depth model for Prášilské jezero. Age-depth relationships were established using ten ${ }^{14} \mathrm{C}$ and a ${ }^{210} \mathrm{~Pb}$ series (Appleby, 1978). The ages were modelled in 'BACON' (Blaauw and Christen, 2011) using the IntCal13 dataset for ${ }^{14} \mathrm{C}$ ages (Reimer et al., 2013). A Student- $t$ distribution was used to account for both scatter in the measurements and statistical outliers.

\subsection{Plant macrofossils and pollen analysis}

To investigate the connection between the local fire history and local vegetation development, plant macrofossils were analyzed at $1-2.5 \mathrm{~cm}$ resolution. Sample volume was measured by measuring the displacement of water (on average $6 \mathrm{~cm}^{3}$ ), and then washed through a 100- $\mu \mathrm{m}$ sieve following Birks (2007). Plant macrofossils (needles, seeds, buds, bud scales, etc.) were counted under a stereomicroscope at $15-45 \mathrm{x}$ magnification and identified with the aid of identification keys (Cappers et al., 2006; Bojňanský and Fargašová, 2007; Katz et al., 
1965; Tomlinson, 1985), and by comparing macrofossils with the reference material stored in the Herbarium at Charles University. Identifiable charred macrofossil particles $>1 \mathrm{~mm}$ were counted in order to support the reconstruction of the local fire history (see section 3.3). Concentrations of plant macrofossils were adjusted to a constant volume of $10 \mathrm{~cm}^{3}$. Seeds from terrestrial herbs and small shrubs (Asteraceae, Epilobium angustifolium, Epilobium sp., Poaceae, Rubus agg.) were summed together to estimate landscape openness.

Pollen analysis was conducted at $1-2 \mathrm{~cm}$ resolution to reconstruct the vegetation history. For each sample, $0.5 \mathrm{~cm}^{3}$ was processed using standard procedures (Faegri et al., 1989). Prior-to pollen processing, a Lycopodium tablet was added to each sample as an exotic tracer to estimate pollen concentration and pollen accumulation rates (PAR; grains $\mathrm{cm}^{-2} \mathrm{yr}^{-1}$ ) (Stockmarr, 1972). A minimum of 500 pollen grains were counted in each sample with the aid of reference material and identification keys (Beug, 2004; Punt 1976 - 1996). Pollen counts were converted into pollen percentages based on the abundance of each pollen type relative to the sum of all identified terrestrial pollen. Total herb percentages were used to estimate landscape openness, while the summed percentages of Plantago lanceolata, Plantago.sp., Triticum-type, Secale-type, and Cerealia-type were used as traditional human indicator species. The pollen profile was divided into statistically significant pollen assemblage zones based on optimal splitting the sumof-squares using the broken-stick model (Bennett, 1996). The plant macrofossil and pollen records were visualized against the calibrated age-depth model using Tilia 2.0.41 software (Grimm, 2004).

\subsection{Charcoal analysis}

\subsubsection{Sample treatment and microscope analysis}



and local fire histories. Microscopic charcoal has been shown to be indicative of regional fire activity within a radius of $20-100 \mathrm{~km}$ of a site (MacDonald et al., 1991; Tinner et al., 1998; Whitlock and Larsen, 2001). Theoretical calibrations between fire and charcoal deposition suggest that macroscopic charcoal peaks most accurately reflect local fires $(<3 \mathrm{~km}$ from coring site), while variations of total macroscopic charcoal abundance reflect regional biomass burning trends ( $\sim 50 \mathrm{~km}$ from coring site) (Higuera et al., 2007, 2010; Peters and Higuera, 2007; Adolf et al., 2017).

Microscopic charcoal was counted on pollen slides and was identified as being black, opaque, and angular in shape (Clark, 1988), while macroscopic charcoal was prepared (after Mooney and Tinner, 2011) by disaggregating contiguous $0.4-1 \mathrm{~cm}^{3}$ samples in a $20 \mathrm{ml}$ solution of dilute sodium hexametaphosphate and $10 \mathrm{ml}$ potassium hydroxide (5\%). Macroscopic charcoal samples were washed gently through a $250-\mu \mathrm{m}$ sieve and then bleached using $1-2 \mathrm{ml}$ of sodium hypochlorite (8\%: $\mathrm{NaOCl}$ ) for the minimum time (up to 12 hours) necessary to achieve a consistent bleaching effect. The bleaching process was carefully monitored as bleach digests charcoal particles that are not fully charred, thus potentially reducing their size, particularly if the sample contains little organic material (Schlachter and Horn, 2010). The samples were then washed gently through a $125-\mu \mathrm{m}$ sieve, and macroscopic charcoal particle counts were recorded with the use of a low power binocular microscope. Charcoal area measurements were made using digital greyscale images using a 137 - 255 greyscale threshold in ImageJ software (https://imagej.nih.gov/ij/). Macroscopic charcoal counts and area measurements were transformed to concentrations (particles $\mathrm{cm}^{-3}$ ) and accumulation rates 
(particles $\mathrm{cm}^{-2} \mathrm{yr}^{-1} ; \mathrm{mm}^{2} \mathrm{~cm}^{-3}$ ). Macroscopic charcoal accumulation rate will be denoted as $\mathrm{CHAR}_{\mathrm{C}}$ (the number of particles $\mathrm{cm}^{-2} \mathrm{yr}^{-1}$ ) and $\mathrm{CHAR}_{\mathrm{A}}$ (the area of particles $\mathrm{mm}^{2} \mathrm{~cm}^{-2} \mathrm{yr}^{-1}$ ).

\subsubsection{Fire episode detection and change point analysis}

To determine the regional fire history, the macroscopic charcoal records $\left(\mathrm{CHAR}_{\mathrm{C}}\right.$ and $\mathrm{CHAR}_{\mathrm{A}}$ ) were first interpolated to a constant temporal resolution (median: 28 years sample ${ }^{-1}$ ), and then broken into a low-frequency component (charcoal background (BCHAR)) and a peak component $\left(\mathrm{CHAR}_{\text {peak }}\right)$ using the CharAnalysis software (Higuera et al., 2009). The BCHAR component was determined using a robust LOWESS regression with a moving-window width of 600 years which resulted in a robust signal-to-noise index $(\mathrm{SNI})>3.0$ (Kelly et al., 2011).

$\mathrm{CHAR}_{\text {peak }}$ values were calculated as residuals from BCHAR, and CHAR $\mathrm{peaks}_{\text {w }}$ were evaluated using the 99th percentile of a Gaussian mixture model that aimed at separating peak samples representing actual fire events from surrounding noise in the $\mathrm{CHAR}_{\text {peak }}$ series. The identified $\mathrm{CHAR}_{\text {peakC }}$ were further screened with the minimum count peak-screening test (Gavin et al., 2006; Higuera et al., 2010). CHAR $_{\text {peakA }}$ were screened with the method proposed by Finsinger et al. (2014) using the software, ARCO ('charcoal ARea-COunts.') v.1.0 (available at github.com/wfinsinger/ARCO). Fire frequencies (fires $\mathrm{kyr}^{-1}$ ) and fire-return intervals (FRI; the total number of years between adjacent fire episodes) were smoothed using a 1000-year window. Lastly, peak magnitude (the total charcoal abundance associated with each fire episode) was used as a qualitative measure of fire severity (Colombaroli et al., 2010; Feurdean et al., 2017; Keeley, 2009; Minckley and Long, 2016; Robichaud, 2000).

Change point analysis was used to determine significant changes in biomass burning based on variations in both the mean and variance of the total CHAR records (Killick et al., 
2012) using the 'change point' v2.2.2 package (Finsinger et al., 2016; Killick et al., 2014; R Core Development Team, 2012). We also tested the potential effect of sedimentation-rate change on change point detection following Finsinger et al. (2016).

\subsection{Regression analysis}

In order to describe the relationship between the dominant forest canopy taxa and changes in fire regimes at Prášilské jezero, a Generalized Additive Model was used (GAM; Hastie and Tibshirani, 1986) using the 'mgcv' v1.8-12 package (Wood, 2006). A GAM is a semi-parametric extension of a generalized linear model that uses a link function to establish a relationship between the mean response variable (i.e. the dependent variable; PAR of the six dominant forest canopy taxa; Abies, Betula, Corylus, Fagus, Picea, and Pinus) and a smoothed predictor variable(s) (i.e. the independent variable; $\mathrm{CHAR}_{\mathrm{A}}$ and peak magnitude) (Birks, 2012). The default setting for GAMs, a Gaussian error distribution and an identity link function, were used in this study. Both the response variables and the predicator variables were logged to stabilize the variance between the two datasets. $P$-values were implemented in the function summary.gam of the 'mgcv' R package, v1.8-12.

\subsection{Climate model}

Locally derived paleoclimate proxies are scarce in central Europe making it difficult to interpret macro-scale changes in climate and their influences on fuel and fire occurrence.

However, previous paleoecological studies have demonstrated the effectiveness of macrophysical climate models (MCM) as independent climate data sources (Dreslerová, 2012; Higgins and MacFadden, 2009; Jamrichová et al., 2014; Kuneš et al., 2015; Riehl et al., 2009). 
The MCM is an alternative to iterative general circulation models (GCMs) and uses a top-down approach rather than a bottom-up approach to model building. While MCMs are simpler than

GCMs, MCMs illustrate the main trends in site-specific climatic changes. Essentially the MCM is a heat-budget model derived from the basic principles of synoptic climatology, and variations in atmospheric transparency, as well as orbital forcing (Bryson, 2005). The model calculates monthly values in 100-year intervals using modules that consist of internal boundary conditions

(i.e., subtropical highs, jet streams and Intertropical convergence), external orbital forcing, and volcanic eruptions for the past 40,000 years. The modules are then assembled into a site-specific model that is calibrated by using a locally derived time series of meteorological data (here, the Churáňov weather station record).

In addition, we compared the MCM model with independent paleoclimate records obtained from public repositories; a stacked reconstruction of July temperature from multiple sites across central Europe (Heiri et al., 2015), and a reconstruction of winter temperature from Spannagel Cave, Austria (Fohlmeister et al., 2013) (Fig. 1).

\section{Results}

\subsection{Reconstructed fire history}

Macroscopic $\mathrm{CHAR}_{\mathrm{C}}$ and $\mathrm{CHAR}_{\mathrm{A}}$ are strongly correlated (Pearson's $r$ coefficient $=0.74$, p-value $<0.001)$. $\mathrm{CHAR}_{\mathrm{C}}$ and $\mathrm{CHAR}_{\mathrm{A}}$ records show similar trends in biomass burning with the highest BCHAR values occurring during the early Holocene between 11,000 and 6500 cal yr BP when CHAR abruptly decreased (Fig. 3). $\mathrm{CHAR}_{\mathrm{A}}$ values increase again briefly $\sim 6000 \mathrm{cal}$ yr BP, between 4600 and $\sim 3300$ cal yr BP, and over the past $\sim 1800$ years. These periods of increased biomass burning correspond to the significant zones detected by change point analysis 
(Fig. 4). Micro-CHAR similarly captures this general trend of increased values between 11,500 and $\sim 8500$ cal yr BP, minimum values between 8000 and $500 \mathrm{cal}$ yr BP, and increasing values over the past 500 years.

The SNI generally exceeded the critical threshold of 3.0 suggesting the records are both suitable for peak-detection analysis during most periods of time (Kelly et al., 2011) (see Appendix Fig. 1). Overall, $\mathrm{CHAR}_{\mathrm{C}}$ identified 30 fire episodes, while $\mathrm{CHAR}_{\mathrm{A}}$ identified 24 fire episodes. Both $\mathrm{CHAR}_{\mathrm{C}}$ and $\mathrm{CHAR}_{\mathrm{A}}$ records show high fire frequencies centered in the early-to mid-Holocene (10,000 - 7000 cal yr BP) and late Holocene (past c. 1,000 years) (Fig. 3a and c), reflecting the regional biomass burning trends derived from the BCHAR record. However, the fire frequency records based on $\mathrm{CHAR}_{\mathrm{C}}$ and $\mathrm{CHAR}_{\mathrm{A}}$ differ between $7000-\sim 1000$ cal yr BP; whereas $\mathrm{CHAR}_{\mathrm{C}}$-inferred fire frequency is low, $\mathrm{CHAR}_{\mathrm{A}}$-inferred fire frequency is stable with the highest values around $2500 \mathrm{cal}$ yr BP. Reconstructed fire frequency based on $\mathrm{CHAR}_{\mathrm{A}}$ suggests an average of c. 3 fires/1000 years $(\mathrm{FRI}=\sim 333$ years) between $10,000-7000 \mathrm{cal}$ yr BP. CHAR fire frequencies were slightly lower (average of 2 fires/1000 years (FRI $=\sim 500$ years)) between $6000 \mathrm{cal}$ yr BP and present, except around $\sim 2500$ cal yr BP when $\mathrm{CHAR}_{\mathrm{A}}$ fire frequency increased to an average of 6 fires/1000 years (FRI $=\sim 166$ years).

While peak magnitudes varied in size $\left(\mathrm{CHAR}_{\mathrm{C}}\right.$ ranged between 0 and 15 particles $\mathrm{cm}^{-2}$ peak $^{-1}$; $\mathrm{CHAR}_{\mathrm{A}}$ ranged between 0 and 3.9 particles $\mathrm{cm}^{-2}$ peak $^{-1}$ ), the records show similar trends of higher peak magnitudes in the early- to mid-Holocene, and lower peak magnitudes after $\sim 6500$ cal yr BP. 

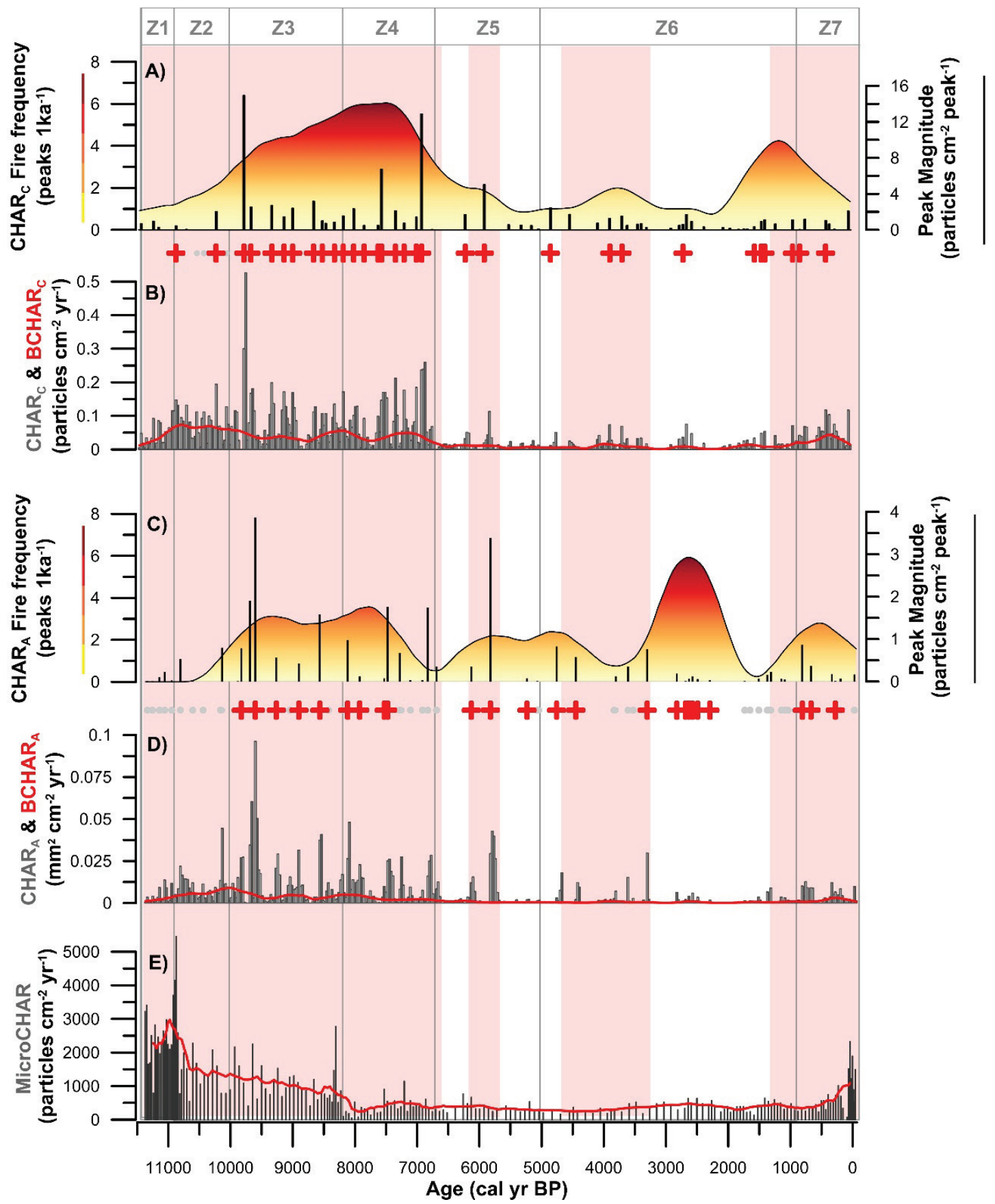

Fig. 3. Reconstructed fire history for Prášilské jezero based on macroscopic charcoal counts $\left(\mathrm{CHAR}_{\mathrm{C}}\right.$ : A-B), macroscopic charcoal areas $\left(\mathrm{CHAR}_{\mathrm{A}}\right.$ : C-D), and microscopic charcoal counts (MicroCHAR: E). A) and C): smoothed fire-frequency records (yellow-red shading), peakmagnitude records (black vertical bars), and significant fire episodes (red crosses) and non- 
significant fire episodes (grey dots); B) and D): macroscopic charcoal accumulation rate (dark grey vertical bars), and the charcoal background records (BCHAR; red continuous line); E): point analysis (see Fig. 4). Grey vertical lines are associated with the statistically significant pollen zones detected by broken stick analysis (labelled Z1 - Z7).
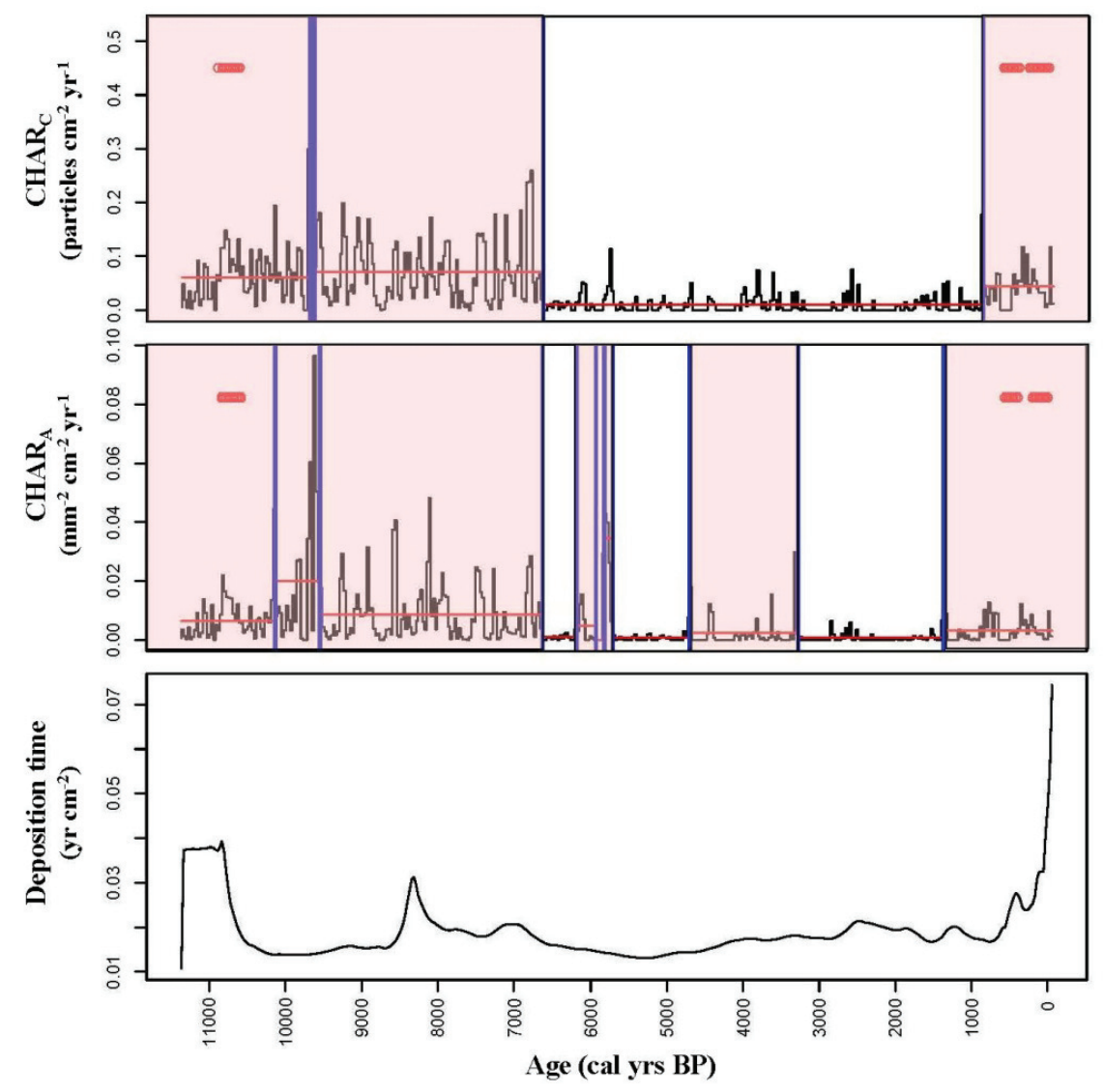

Fig. 4. Comparison between change point analysis based on macroscopic charcoal counts $\left(\mathrm{CHAR}_{\mathrm{C}}\right.$; top), macroscopic charcoal area $\left(\mathrm{CHAR}_{\mathrm{A}}\right.$; middle), and sample deposition time 
(bottom) for Prášilské jezero. Vertical blue lines indicate change points in the CHAR records. Primary zones of elevated biomass burning are depicted by the areas shaded in pink.

\subsection{Reconstructed vegetation history}

The pollen percentage profile was divided into seven statistically significant pollenassemblage zones. Zones $1-4(11,500-6700$ cal yr BP) are characterized by high percentages of Pinus, Corylus, Betula and herbs (Fig. 5). High concentrations of Pinus, Betula, herbs, and charred macrofossil remains $(>1 \mathrm{~mm})$ were also found throughout Zones $1-4$ (Fig. 5). High concentrations of Juncus macrofossil remains were also present during Zones 1 - 4 (See Appendix Fig. 2). During Zone 3 (10,000 - 8300 cal yr BP), Picea pollen percentages increased, as did Picea macrofossil concentrations and the appearance of Picea stomata, suggesting the local establishment and rise to dominance of Picea. Zone 4 (8300 - 6700 cal yr BP) illustrates the dominance of Picea when Corylus was still abundant (Fig. 5), and when biomass burning was at its highest (Fig. 3). Fagus pollen percentages increase towards the end of Zone 4 ( 7000 cal yr BP) suggesting the local establishment of beech. The boundary between Zones 4 and 5 (c. 6700 cal yr BP) marks the transition of Fagus becoming a secondary component of the canopy cover (comprising > $20 \%$ of the canopy). Towards the end of Zone 5, Abies pollen percentages increase, yet Abies macrofossil concentrations do not appear until Zone 6. The earliest findings of human pollen indicator species occur in Zone 5. Around 2500 cal yr BP (middle of Zone 6; 5100 - 1000 cal yr BP), human pollen indicator species increase briefly, then decrease, and then dramatically increase again starting $\sim 1000 \mathrm{cal} \mathrm{yr} \mathrm{BP} \mathrm{(onset} \mathrm{of} \mathrm{Zone} \mathrm{7).} \mathrm{The} \mathrm{latter} \mathrm{half} \mathrm{of} \mathrm{Zone} \mathrm{6,}$ as well as Zone 7 are characterized by the decline in Fagus and Abies pollen percentages, and the increase in herb pollen percentages and herb macrofossil concentrations (i.e. landscape openness). 

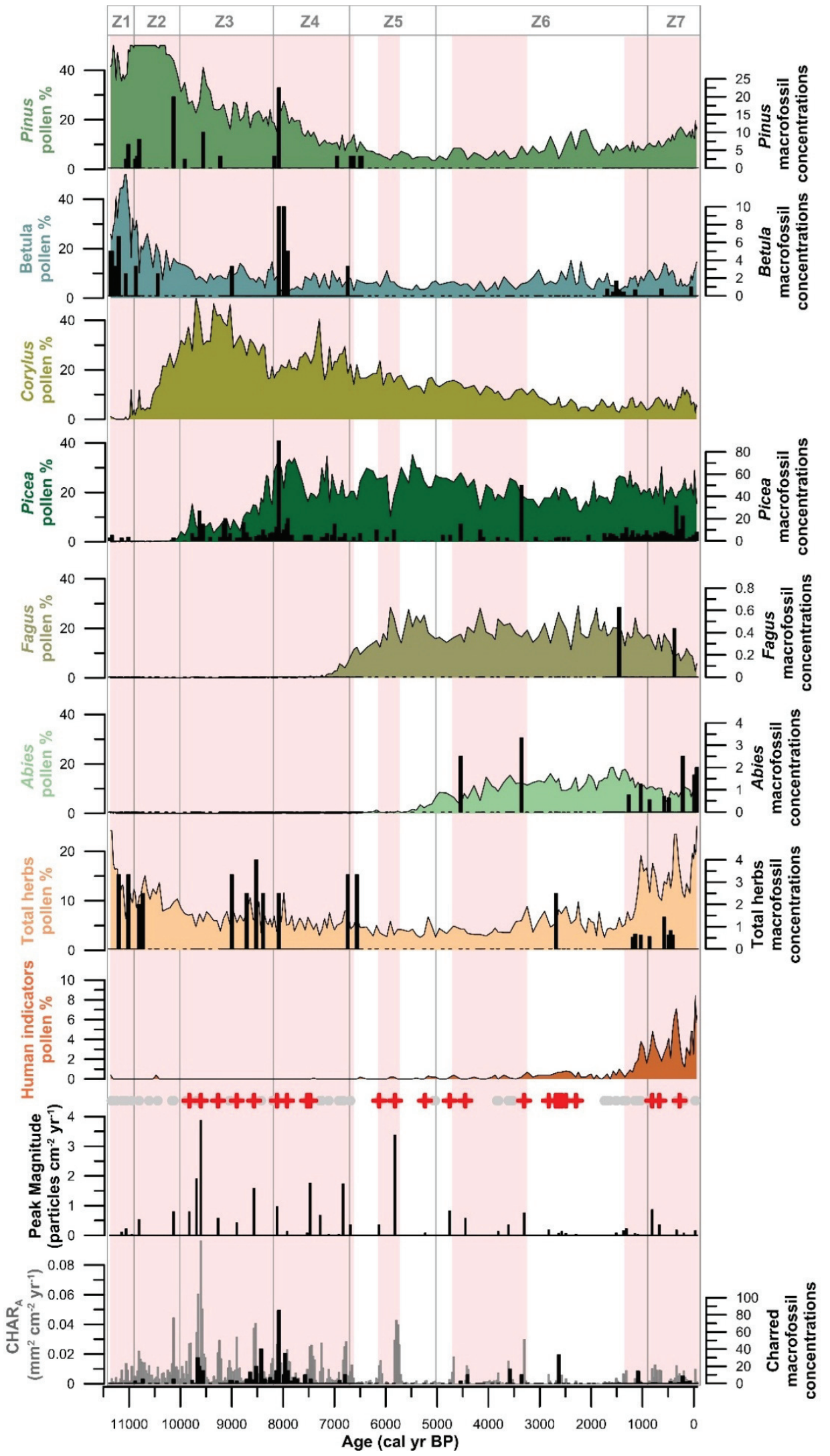
Fig. 5. Reconstructed vegetation history of the dominant forest canopy taxa at Prášilské jezero using pollen percentages (filled coloured lines), and macrofossil data (black bars). Vegetation data are compared to significant fire episodes (red crosses), non-significant fire episodes (grey dots), peak magnitude (black vertical bars), $\mathrm{CHAR}_{\mathrm{A}}$ (grey vertical bars), and the concentration of charred macrofossil remains (black vertical bars). All y-axes were clipped at 50\%. Pink vertical bands highlight periods of higher $\mathrm{CHAR}_{\mathrm{A}}$ values as detected by change point analysis (see Fig. 4). Grey lines are associated with the statistically significant pollen zones detected by broken stick analysis (labelled Z1 - Z7).

\subsection{Regression analysis}

Response curves show that Betula, Corylus and Pinus have a statistically significant positive relationship (e.g. at the $95 \%$ confidence interval) with increased biomass burning (i.e. $\mathrm{CHAR}_{\mathrm{A}}$ ), whereas Fagus has a statistically significant negative relationship (Fig. 6a; Table 1). While not statistically significant, Corylys illustrates a positive relationship with increasing fire severities, while Betula, Fagus, and Pinus all have a negative relationship (Fig. 6b). Picea has a slightly negative relationship with increased biomass burning, and a slight positive relationship with increasing fire severities (Fig 6b), but these trends are not statistically significant. While Abies shows a relatively positive relationship to both increased biomass burning and fire severities, these relationship are too weak to make inferences about the species relationship with fire in this study (Fig. 6a). 

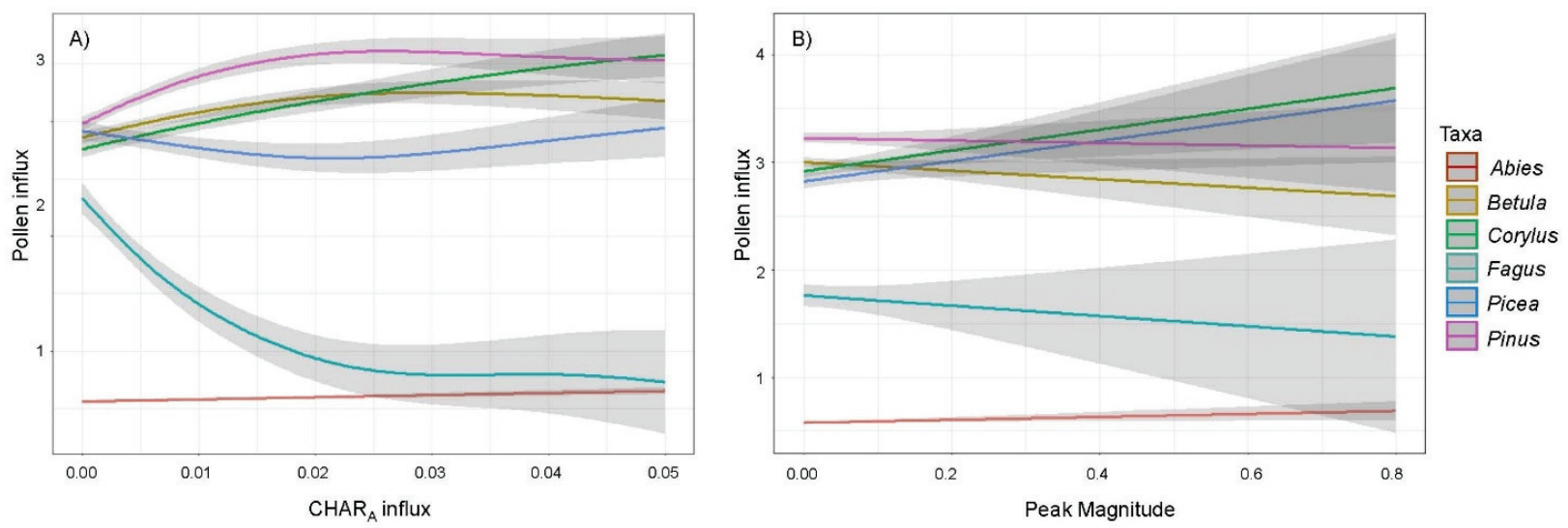

Fig. 6. Taxa response curves illustrating the relationship between pollen accumulation rates of

the six dominant forest canopy species and increases in biomass burning (i.e. $\left.\mathrm{CHAR}_{\mathrm{A}}\right)(\mathrm{A})$, and

fire severity (i.e. peak magnitudes) (B). A) Response curves illustrate three different responses to

changing fire regimes at Prášilské jezero, which correspond to fire resistance (Betula, Corylus,

illustrate a positive relationship with increasing fire severity.

\begin{tabular}{|c|c|c|c|c|c|c|}
\hline Species & CHAR $_{\mathbf{A}}$ & CHAR $_{\mathbf{A}}$ & CHAR $_{\mathbf{A}}$ & Peak Magnitude & Peak Magnitude & Peak Magnitude \\
\hline names & r2 adj. & p-value & df & r2 adj. & p-value & df \\
\hline \hline Abies & 0.03 & 0.009 & 2 & 0.0155 & 0.348 & 4.675 \\
\hline Betula & 0.056 & 0.009 & 3.575 & -0.003 & 0.623 & 2 \\
\hline Corylus & 0.77 & $<0.001$ & 2.742 & 0.0354 & 0.116 & 5.372 \\
\hline Fagus & 0.162 & $<0.001$ & 4.387 & -0.002 & 0.508 & 2 \\
\hline Picea & 0.008 & 0.419 & 3.342 & 0.003 & 0.191 & 2 \\
\hline Pinus & 0.132 & $<0.001$ & 4.38 & -0.005 & 0.867 & 2 \\
\hline & & & & & & \\
\hline & & & & & & \\
\hline
\end{tabular}

Table 1. Correlation between the dominant forest canopy taxa and macroscopic charcoal area

$378\left(\mathrm{CHAR}_{\mathrm{A}}\right)$ and peak magnitudes at Prášilské jezero, as determined by a Generalized Additive

379 Model. 


\subsection{Reconstructed climate}

The MCM model provided monthly means of temperature and evaporation in 100-year intervals (Fig. 7C, D, G). Specifically, we selected averages of monthly means for winter (DJF) and summer (JJA) temperature, and summer potential evaporation (AE/PE) in order to compare with regional climate data. Two main climatic phases are present in the MCM model after the postglacial warming from 11,500 to $\sim 9500$ cal yr BP. The first phase between 9500 and $\sim 5500$ cal yr BP was characterized by relatively low winter temperatures, higher-than-present summer temperatures, and higher-than-present potential evaporation during the summer (i.e. warmer and drier-than-present summer conditions). The second phase between $\sim 5500 \mathrm{cal}$ yr BP and present was characterized by gradually increasing winter temperatures, decreasing summer temperatures, and decreasing potential evaporation during the summer (i.e. gradually cooler and wetter-thanprevious summer conditions). Overall, the MCM outputs reflect the long-term millennial-scale trends in winter and summer temperatures derived from regional proxy records (Fig. 7E, F). 


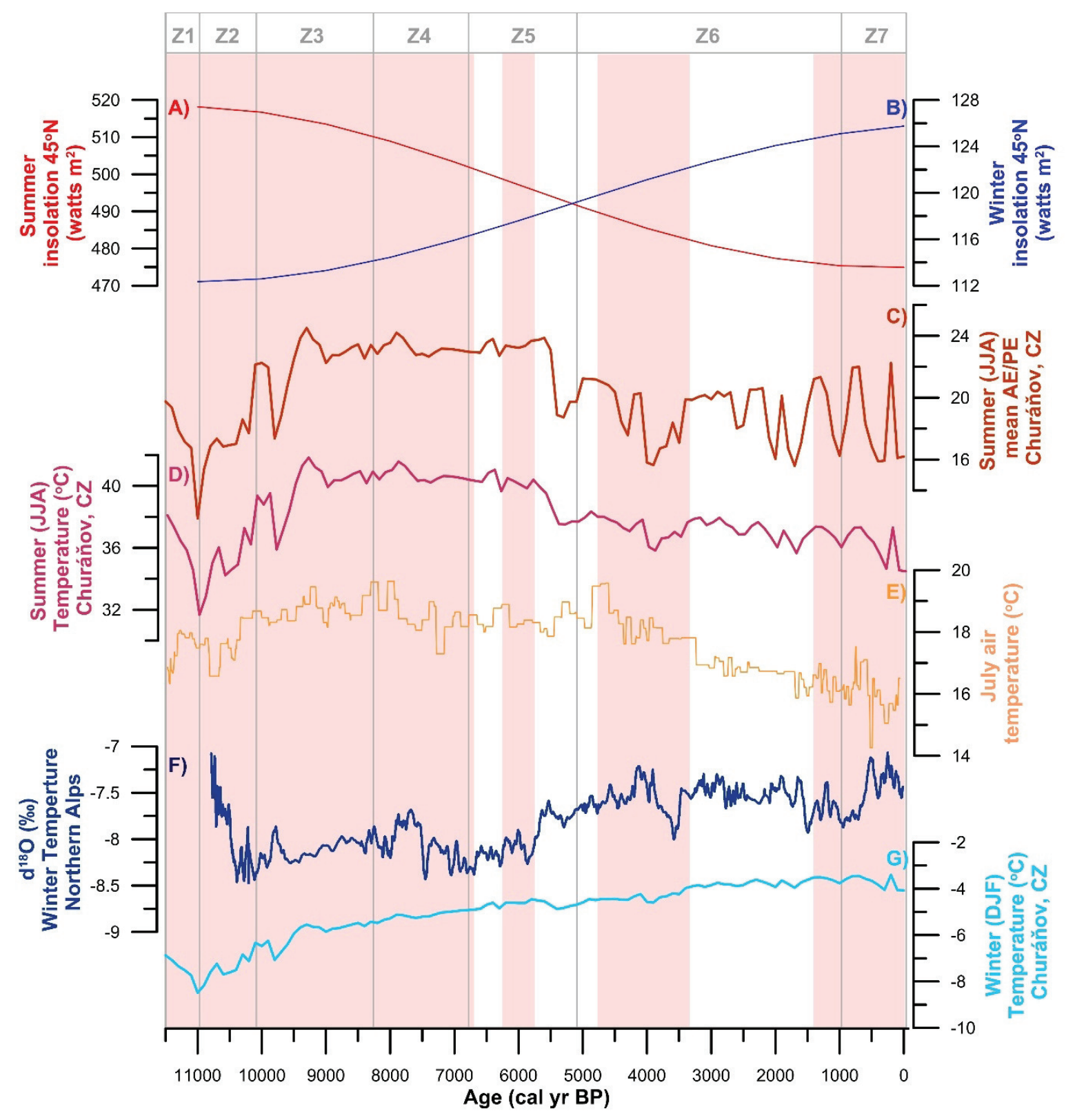

Fig. 7. Reconstructed climate from central Europe. A) summer and B) winter insolation curves for $45^{\circ} \mathrm{N}$ (Berger and Loutre, 1991); C) reconstructed summer AE/PE based on the MCM model, (this study); D) reconstructed summer temperature based on the MCM model (this study); E) reconstructed July temperature based on a stacked chironomid record from multiple sites across central Europe (Heiri et al., 2015); F) reconstructed winter temperature based on $\delta^{18} \mathrm{O}$ isotopes from Spannagel Cave, Austria (Fohlmeister et al., 2013); G) reconstructed winter temperature 
based on the MCM model (this study). Pink vertical bands highlight periods of higher $\mathrm{CHAR}_{\mathrm{A}}$ values as detected by change point analysis (see Fig. 4). Grey vertical lines are associated with the statistically significant pollen zones detected by broken stick analysis (labelled Z1 - Z7).

\section{Discussion}

\subsection{Using charcoal area to infer the local fire history}

Reconstructed $\mathrm{CHAR}_{\mathrm{C}}$ and $\mathrm{CHAR}_{\mathrm{A}}$ from Prášilské jezero illustrate similar long-term patterns of higher biomass burning in the early-to mid-Holocene, and lower biomass burning after 6500 cal yr BP (Fig. 3). The similarity supports previous studies reporting a strong correlation between macroscopic charcoal count and area data (Finsinger et al. 2014; Tinner and $\mathrm{Hu}, 2003)$.

Unlike the similarities in $\mathrm{CHAR}_{\mathrm{C}}$ and $\mathrm{CHAR}_{\mathrm{A}}$, there appears to be differences in the reconstructed fire episodes and fire frequency using both macroscopic charcoal counts versus area. These differences could be associated with lab treatment and/or different user-defined parameters within the software used (e.g. CharAnalysis and ARCO). For example, low count sums in proxy data have been shown to reduce strongly the accuracy of palaeoecological reconstructions (Finsinger and Tinner, 2005; Heiri and Lotter, 2001; Maher, 1972; Maher et al., 2012). Charcoal counts were consistently low at Prášilské jezero and did not meet the preferred rule of thumb that non-peak samples have $>10$ charcoal pieces and peak samples have at least 20 charcoal particles (Higuera et al., 2010). This likely made the identification of statistically significant peaks difficult. Patterns of fire frequencies have been shown to vary little based on charcoal counts and area data both without peak-screening tests (Ali et al., 2009), and with peakscreening tests (Finsinger et al., 2014). By contrast, here we demonstrate that patterns of fire 
frequencies and detected peak episodes differ substantially between charcoal counts and area data. We suggest that low charcoal counts could have contributed to the different reconstructed fire frequencies and detected fire episodes. Despite these limitations, here we infer relationships between vegetation-dynamics and fire-frequency changes based on charcoal area rather than charcoal counts. While it might be difficult to determine the spatial scales of fire frequency and fire return interval (FRI) with CHAR records comprising particles $>150 \mu \mathrm{m}$ as in our study (Adolf et al., 2017), support for this comes from the area-based screening-peak test (Finsinger et al., 2014), which should reduce the influence of small charcoal particles derived from regional background of CHAR (Tinner et al., 1998; Adolf et al., 2017).

\subsection{Drivers of fire regimes in central European montane spruce-beech forests}

The history of fire in Europe is a complex product of top-down (i.e. climate) and bottomup (i.e. vegetation dynamics and human activities) drivers (Pyne, 2000). The Prášilské jezero fire history reflects how these drivers facilitated in changing fire regimes over time. In the early Holocene, broad-scale climatic forces such as the high contrast between colder-than-present winters and warmer-than-present summers (Per $\square$ oiu et al., 2017), and high summer insolation induced warmer- and drier-than-present conditions (Fig. 7; Davis et al., 2003, Heiri et al., 2003, Litt et al., 2009), resulted in fuel type more conducive for high and regionally synchronous biomass burning. Fuel composition at Prášilské jezero was dominated by Pinus and Corylus in addition to continuous fire-promoting fuels in the form of understory herbs in the early Holocene (Fig. 5). While pollen and macrofossil analysis were unable to conclude whether $P$. mugo or $P$. sylvestris dominated in the early Holocene, both $P$. mugo and $P$. sylvestris are favored by frequent, low-intensity surface fires (Zackrisson, 1977; Delcourt and Delcourt, 1987; Engelmark 
et al. 1994; Adámek et al., 2015). Thus either species would have benefited from the frequent fire activity documented in the early Holocene. Corylus avellana is also known to colonize early and spread quickly after fires (Delarze et al., 1992). However, because Corylus maxima also occurred during previous Interglacials when conditions were drier-than-present (Wright, 1977), the high abundance of Corylus in the early Holocene further supports that conditions were drierthan-present. We thus interpret causality between relatively high fire frequency, high Corylus abundance, and drier-than-present conditions at Prášilské jezero in the early Holocene, supporting earlier formulated hypotheses (Huntley, 1993; Finsinger et al., 2006). High fire activity and increased abundances of Corylus and Pinus have also been observed throughout central Europe during this time (Feurdean et al., 2013; 2017; Finsinger et al 2006; Tinner et al., 1999).

Picea abies established and expanded during the early Holocene when regional biomass burning and local fire severity were the highest of the entire record. Regionally, Picea abies persisted throughout the Holocene in the Carpathians, enduring a low-to-moderate fire regime and a variable FRI of 200 - 300 years (Feurdean et al., 2017), and 1000 - 4000 years (Finsinger et al. 2016), which agrees with the estimated fire reoccurrence period in central European mountain spruce forests (Tinner et al., 1999; Beer and Tinner, 2008). Previous paleoecological studies documenting the expansion of Picea abies during periods of increasing fire activity (Brown and Giesecke, 2014; Carcaillet et al., 2007) suggest that the combined effect of increased fuel loads and periodic summer drought resulted in dry surface layers suitable for combustion (Brown and Gisecke, 2014). Thus, the drier-than-present climatic conditions could have supported the high biomass burning when Picea abies dominated in the early Holocene. Our results support the findings of Feurdean et al. (2017) and Finsinger et al. (2016) in that Picea was 
able to expand and persist in the early Holocene because climate conditions were dry enough (high summer AE/PE ration; Fig. 7C) to sustain high regional biomass burning with a relatively high fire frequency and moderate-scale fire severity.

High biomass burning may have also been a result of Upper Paleolithic and Mesolithic hunter and gatherers and their land-use activities, whom occupied the Šumava Mountains between 13,950 - 7500 cal yr BP (Čuláková et.al., 2012b; Vencl, 2006; Fröhlich, 2009; Šida et al., 2011; Eigner et al., 2017). Mesolithic finds have been connected with the seasonal exploitation of food resources, such as fishing and hunting, and the late summer source of berries e.g. Vaccinium and Oxycoccus (Oliver, 2007), which mature later at higher elevations $>500 \mathrm{~m}$ a.s.l. Additionally, they would have exploited the high abundances of Corylus nuts (Divišová and Š́da, 2015), which was one of the dominant canopy species found regionally in the early Holocene (Svobodová et al., 1996; 2000; 2002). While estimating the extent and magnitude of fires caused by hunters and gatherers is difficult, Kaplan et al. (2016) suggest that huntergatherers had mastered fire as a tool for landscape management, and for improving hunting and foraging opportunities during the Last Glacial Maximum (LGM). However, increased burn area during the LGM generally resulted in large reductions in forest cover (Kaplan et al., 2016). However, in the early Holocene, there was no significant reduction in forest cover, nor any significant increase in herbaceous pollen (i.e. landscape openness) (Carter et al., 2018), or traditional anthropogenic pollen indicators at Prášilské jezero (Fig. 5). Additionally, Corylus maxima also occurred during previous Interglacials (Wright, 1977) when human activities were unlikely to have been a factor (Finsinger et al., 2006). Thus, despite the archeological evidence suggesting humans occupied the region during the early Holocene, we conclude that because the trend in biomass burning was similar to other records across Europe (Feurdean et al., 2012; 
Finsinger et al., 2006; Olsson et al., 2010; Vanniére et al., 2016), as well as with global biomass burning syntheses (Marlon et al. 2013; Power et al. 2008), climate and type of fuel were the primary drivers of biomass burning at the regional-to-subcontinental-scale, but acknowledge that local-scale human activities could have influenced the local fire regime (see Valese et al., 2014). During the mid-Holocene, broad-scale changes in climate resulted in major shifts in vegetation composition, and subsequently a decline in global biomass burning (Marlon et al., 2013; Power et al., 2008). As summer insolation decreased, winter insolation increased resulting in the long-term trend of increasing winter temperature (Fig. 7F, G). This led to the decline in the strength of the westerlies inducing wetter and milder-than-previous winter conditions across Europe (Benito et al., 2015). Pollen-based climate reconstructions highlight winter temperature as the most important driver of mid-to late-Holocene warming in Europe (Mauri et al., 2015). Because Fagus sylvatica is sensitive to cold winter temperatures and spring frost (Cheddadi et al., 2017), it is likely that the spread of Fagus across Europe during the mid-Holocene, while not spatially synchronous, may have been limited by colder-than-present winter temperatures (Fig. 7F, G). Feurdean et al. (2017) attributed the expansion of Fagus to either climate or a combination of climate, fire, and human disturbances. Yet, Giesecke et al. (2007; 2017) suggest that no single variable, such as climate, disturbances, or intrinsic biological factors can explain the changes in Fagus distribution and abundance. Regardless of the causes leading to the expansion of Fagus on regional to subcontinental-scales, the reconstructed $\mathrm{CHAR}_{\mathrm{C}}$ and $\mathrm{CHAR}_{\mathrm{A}}$ corroborate the notion that once beech established as one of the main canopy species, regional biomass burning declined illustrating bottom-up controls on biomass burning (Fig. 5). Because regional biomass burning decreased with the expansion of beech forests, it can be assumed that the local fire frequency would also decrease, yet the local fire frequency 
remained relatively similar to that seen during the early Holocene (Fig. 3). Submontane beech forests in central Europe are considered to have a low frequency fire regime with few fires occurring under extreme climatic conditions (Xanthopolous et al., 2012). For example, beech forests in the Southern Alps experienced numerous, large fires under hot and dry weather during the extremely dry summer of 2003 (Ascoli et al., 2013). Thus, the relatively stable local fire frequency may be explained by complex interactions between climate and local human activities. Chironomid- and pollen-based temperature reconstructions from Europe illustrate that summer temperatures reached a maximum between $\sim 6500$ cal yr BP (Heiri et al., 2003) and $6000 \mathrm{cal} \mathrm{yr}$ BP (Davis et al., 2003), which would have led to an increase in fire potential as a result of drier fuel loads (Daniau et al., 2012). Coincidentally, between 6500 and 6000 cal yr BP, two local fire events occurred simultaneous with a brief increase in regional biomass burning (Fig. 3). We therefore suggest that the increase in biomass burning and two local fire events between 6500 and 6000 cal yr BP may be explained by fire conducive climatic conditions, despite the change in more mesic fuel type during the mid-Holocene.

However, climate alone cannot explain the relatively stable local fire frequency, as the continuous presence of human pollen indicators beginning $\sim 6500 \mathrm{cal}$ yr BP could also suggest Neolithic human-induced influences on the fire regime in the region (Fig. 5). Despite the fact that there is no direct evidence of human activities ca. 35 - 40 km from Prášilské jezero $\sim 6500$ cal yr BP (Dreslerová, 2016; Sommer, 2006), the timing of human indicators from Prášilské jezero agrees with other records from the region suggesting Neolithic presence (Svobodová et al., 2001; Svobodová 2002; 2004). Moreover, the appearance of hill-forts and hill-top settlements in the region, as well as archaeological evidence from two sites $\sim 5 \mathrm{~km}$ from Prášilské jezero suggests the local settlement and occupation of humans during the Bronze and Iron Ages $\sim 3000$ 
and at 2200 cal yr BP (Čuláková et al. 2012a; unpublished data; Dreslerová, D. unpublished data), which correlates with the increases in human indicator pollen types (Fig. 5). Thus, the increase in local fire frequency and fire occurrence $\sim 2500$ cal yr BP can be explained by the presence of local Iron Age activities (Fig. 3). Cooler and wetter-than-previous summer conditions likely inhibited regional fire occurrence (Fig. 7C, D, E), which is why this time period was not identified as a statistically significant zone according to change-point analysis (Fig.4), and why fires were of low severity as suggested by peak magnitudes (Fig. 3). However, fire frequency was sufficiently high to trigger landscape openness and alter the forest canopy composition with a slight decrease in spruce and brief increases in early-successional species (i.e. Pinus and Betula) around 2500 cal yr BP (Fig. 5). As suggested by Kaplan et al. (2016), the reductions in forest canopy in combination with increases in fire frequency $\sim 2500$ cal yr BP further support human presence. Human activities over the last 500 years have significantly altered the local forest composition, as shown by the general decline in Fagus and Abies, and subsequent increase in landscape openness (Fig. 5). The decline in these two species over the past 500 years is the result of intensive deforestation related to the glass industry and expansion of pasture-land (Beneš, 1996).

\subsection{Dominant forest canopy responses to varying fire regimes in central Europe}

Fire parameters such as fire frequency, severity, and drivers of biomass burning are not fully understood in central European primary spruce-beech forests. Vegetation composition and their species-level morphological traits significantly influenced the fire regime at Prášilské jezero throughout the Holocene by creating mosaics of different fire regenerative strategies.

Specifically, we found three types of fire regenerative strategies; taxa that are classified as either 
fire resistant, avoidant, or sensitive/intolerant (Fig. 6). Fire resistant taxa typically have thick bark which protects the cambium and increases the species' chance of survival (Nikolov and Helmisaari, 1992; Richardson and Rundel, 1998). Fires are typically more frequent when fire resistant taxa dominate because of their low fire-induced mortality rates (Wooster and Zhang, 2004; Rogers et al., 2015). Not surprising, during the early Holocene when biomass burning was the highest and fire severity was of moderate-scale, fire resistant taxa (Pinus, Betula, and Corylus) dominated the landscape (Fig. 5). Modeled fire resistant taxa response curves clearly demonstrate a positive response $(p<0.01)$ to increasing biomass burning (Table 1). Pinus sylvestris is currently widespread throughout northern and central Europe (Fernandes, 2009), and was the dominant tree species in Europe during the early Holocene (Giesecke et al., 2017). We infer the species was likely present at Prášilské jezero in the early Holocene. P. sylvestris responds favorably to fire as it possesses fire resistant morphological traits that enabled it to survive the low-to-moderate fire intensities (Zackrisson, 1977) documented in the early Holocene (Fig. 3). Pinus response curves demonstrate a negative relationship with increasing fire severity (Fig. 6), further supporting that this species dominated in the early Holocene because of the moderate-scale fire regime. Betula and Corylus are also considered fire resistant taxa because of their morphological traits which allow the species to quickly colonize post-disturbance soils and resprout vegetatively (Bradshaw et al. 2010; Delarze et al., 1992; Niklasson \& Granström 2000; Feurdean et al., 2017). Betula is able to outcompete other species on freshly exposed mineral soil (Clark et al., 1989), and Corylus is considered a fire-enhanced shrub (Tinner et al., 2000). Interestingly, while not significant the Corylus response curve suggest a positive relationship with increasing fire severity (Fig. 6). Together, the fire resistant morphological traits 
described above support the recruitment and dominance of Pinus (likely P. sylvestris), Betula, and Corylus during the early Holocene.

Fire avoidant taxa typically lack fire-adapted traits such as thick bark, and are usually found in mesic environments where fires are infrequent (Rogers et al., 2015). Picea abies is considered a fire avoider because it lacks morphological traits that allow it to survive or recolonize quickly after a fire (Feurdean et al., 2017; Zackrisson, 1977; Pennanen, 2002).

Specifically, Picea abies has thin bark and shallow roots making it susceptible to both drought and fire (Zackrisson, 1977). However, its low hanging branches create ladder fuels conducive for crown fires during extreme climatic events (Grooth et al., 2013; Rogers et al., 2015; Feurdean et al., 2017). Because of these morphological traits, we would expect a drastic change in biomass burning with the arrival and expansion of Picea. Yet, the establishment and expansion of Picea occurred when fire resistant taxa were still abundant (Fig. 5), and when biomass burning was at its highest and most severe of the entire record (Fig. 3). Our results agree with other paleoecological records that also document an increase in Picea during a period of high fire activity (Carcaillet et al., 2007; Brown and Gisecke, 2014; Clear et al., 2015). However, there appears to be some discrepancy regarding spruces' relationship with fire. For example, both Clear et al. (2015) and Finsinger et al. (2016) documented the subsequent decline in fire activity once Picea established as the dominant canopy, which differs from our findings. Feurdean et al. (2017) also documented the decline in Picea abies abundance during times of increased fire severity/area burned in the Carpathians Mountains. Lastly, Ohlson et al. (2011) synthesized 75 macroscopic charcoal records throughout Scandinavia and found that the expansion of Picea in the late Holocene caused the decline in fire activity across the region by altering microclimate conditions. While not statistically significant, the modeled response curve for Picea abies does 
not show a dramatic decrease to increasing biomass burning (Fig. 6; Table 1). Rather, response curves illustrate a positive relationship between Picea and increasing fire severity (Fig. 6).

Rogers et al. (2015) found that fire avoidant forests in Eurasian boreal forests exhibit significantly higher severity metrics than fire resistant forests, highlighting the contradictions in fire-related traits of Picea abies. The modeled response of Picea may suggest that central European temperate spruce forests may not be as severely impacted by high levels of biomass burning, and may benefit from infrequent high-severity fires. However, additional research is needed to validate this relationship.

Lastly, similar to fire avoidant taxa, fire sensitive/intolerant taxa do not have fire-adaptive traits. Fagus sylvatica is considered to be fire sensitive because of its morphological traits such as relatively thin bark and shallow root systems, and the lack of persistent resprouting capabilities (Peters, 1997; Packham et al., 2012). Not surprising, the greatest change in regional biomass burning occurred when Fagus expanded $\sim 6500$ cal yr BP. The modeled Fagus response clearly illustrates this statistically significant negative relationship with increases in biomass burning, as well as with increasing fire severity (Table 1). These modeled results are similar to those made by Tinner et al. (2000) who demonstrated a negative relationship with Fagus pollen and increasing charcoal influxes. The authors classified Fagus as fire sensitive because fires typically result in considerable decreases in the species, but surprisingly does not result in local extinction (Tinner et al., 2000). Recent field observations demonstrate the potential of beech in taking advantage of newly exposed soils after a single, mixed severity fire event (van Gils et al. 2010; Maringer et al., 2012; Ascoli et al., 2013), by favoring seed germination and seedling emergence, and promoting diffuse light conditions via canopy openings (Ascoli et al., 2015). Several paleoecological records from central Europe also demonstrate the benefit of mixed 
severity fire regimes in beech forests (Tinner et al., 1999; Tinner and Lotter, 2006; Giesecke et al., 2007). Beech can persist in a mixed severity fire regime as long as the fire return interval are $>50$ years, which allows for trees to reach reproductive maturity (Ascoli et al., 2015). High severity fires result in low seed production (Ascoli et al., 2015), which is supported by the modeled response curve (Fig. 6b), and support existing literature that suggest that high-severity fires are detrimental to the species. However, the modeled response curve does not support the notion that mixed severity fires are beneficial for beech propagation. This could be explained by the fact that our results are from a relatively high-elevation lake where spruce has been the dominant forest canopy taxa for the past $\sim 9000$ years (Carter et al., 2018). Thus, these results may not be representative of true beech-fire dynamics. Additional long-term research is needed from pure beech and/or beech dominated forests to determine whether infrequent mixed severity fires are beneficial in these forested systems.

Pollen and charcoal-based taxa response curves offer a deeper insight into the full suite of ecological responses that may occur under future climate change. For instance, climate models project a $3^{\circ} \mathrm{C}$ increase in temperatures in central Europe (Christensen et al., 2007), which may increase the likelihood of more frequent and intense summer droughts across central and southern Europe (Gao and Giorgi, 2008; Feyen and Dankers, 2009). As a result, the risk of fire across central Europe is predicted to increase (Lung et al., 2013). Together, increased summer droughts and fire risk may be detrimental for primary spruce and beech forests. Spruce is likely to be the species most impacted by climate change (Bolte et al., 2009), with projections predicting the loss of available habitat for spruce (Hanewinkel et al., 2012). Since 1920, reduced rates of disturbance have contributed to the increase in disturbance susceptibility among primary spruce forests across central and eastern Europe (Schurman et al., 2018) highlighting the species' 
vulnerability to increasing exposure to extreme climatic events. Where beech naturally predominates will also likely be threatened with increasing temperatures (Cheddadi et al., 2016). Response curves demonstrate the fragility of primary beech forests to increased biomass burning, while spruce forests may benefit from increased biomass burning. However, additional long-term fire history research is strongly encouraged from central European primary spruce-beech forests to determine how sensitive these forests may be as a result of changing fire regimes.

\section{Conclusions}

Currently, fire is considered a negligible disturbance agent in central European temperate forests. Yet, the results of this study support emerging literature demonstrating that fires have been an important disturbance agent throughout the Holocene in temperate forests (e.g. Clark et al., 1989; Bobek et al. 2017; Niklasson et al., 2010; Novák et al. 2012). The results of this study also illustrate the complex relationship between the primary drivers of fire (i.e. climate, vegetation type, and human activities) in influencing the long-term fire regime. Climate and vegetation type were likely the dominant drivers responsible for synchronizing regional biomass burning in central Europe in the early Holocene. However, we acknowledge that human occupation beginning as early as the Upper Palaeolithic/Mesolithic period may have contributed to the local fire regime, but likely did not override climate as the dominant driver in the early Holocene. When climatic conditions became more favorable for the more fire sensitive species Fagus beginning $\sim 6500$ cal yr BP, regional biomass burning decreased. However, local fire frequency only slightly decreased to an average of 2 fires/1000 years suggesting the relative importance of either humans and/or rare fire-promoting climatic events post $6500 \mathrm{cal} \mathrm{yr} \mathrm{BP}$. Human activities had a clear impact on the local fire regime $\sim 2500$ cal yr BP when the local fire 
frequency increased to 6 fires/1000 years simultaneous to small increases in human pollen indicators and small-scale changes in the forest canopy. Drastic changes in forest canopy occurred over the past 1000 years as a result of human land-use activities, resulting in increases in regional biomass burning and landscape openness.

Vegetation composition significantly influenced the local fire regime at Prášilské jezero, creating mosaics of different fire regenerative strategies; taxa that are classified as either fire resistant, avoidant, or sensitive/intolerant. Response curves demonstrate that fire resistant taxa Pinus, Betula, and Corylus thrived under high biomass burning, and a relatively frequent fire regime comprised of moderate-scale fire severities during the early Holocene. Picea, established $\sim 10,000$ cal yr BP and became the dominant canopy species by $\sim 9000$ cal yr BP. The rise of Picea occurred when biomass burning and fire severities were the highest of the entire record. While not statistically significant, response curves for this fire avoidant taxa suggest that Picea may be less impacted by fire than conventionally thought. Finally, response curves for the fire sensitive taxon, Fagus demonstrate the species intolerance to increased biomass burning and fire severities. These modeled response curves disagree with emerging literature suggesting beech forests may benefit from an infrequent ( $>50$ years/fire) and mixed severity fire regime (Ascoli et al., 2015). Rather, response curves demonstrate the fragility of primary beech forests to increased biomass burning, while response curves suggest that primary spruce forests may benefit from increased biomass burning. However, additional research is necessary from central European spruce-beech forests to determine whether these modeled response curves are valid.

As climate projections forecast a $3^{\circ} \mathrm{C}$ increase in temperatures in central Europe (Christensen et al., 2007), as well as the increased likelihood in extreme climate events such as more frequent and intense heat-waves and drought (Gao and Giorgi, 2008; Feyen and Dankers, 
2009; Rajczak et al., 2013; Seneviratne et al. 2012), these variables will likely lead to the increased risk of wildfire in central Europe. With an increase in temperatures, heat stress, and increased risk of wildfires (Lung et al., 2013), primary spruce and beech forests may be the one of the most vulnerable forested ecosystems to climate change. Additional long-term fire histories from central European temperate forests are crucial to determine how vulnerable spruce-beech forests are to anthropogenically-induced climate change and increasing fire risk.

\section{Supplementary Information}

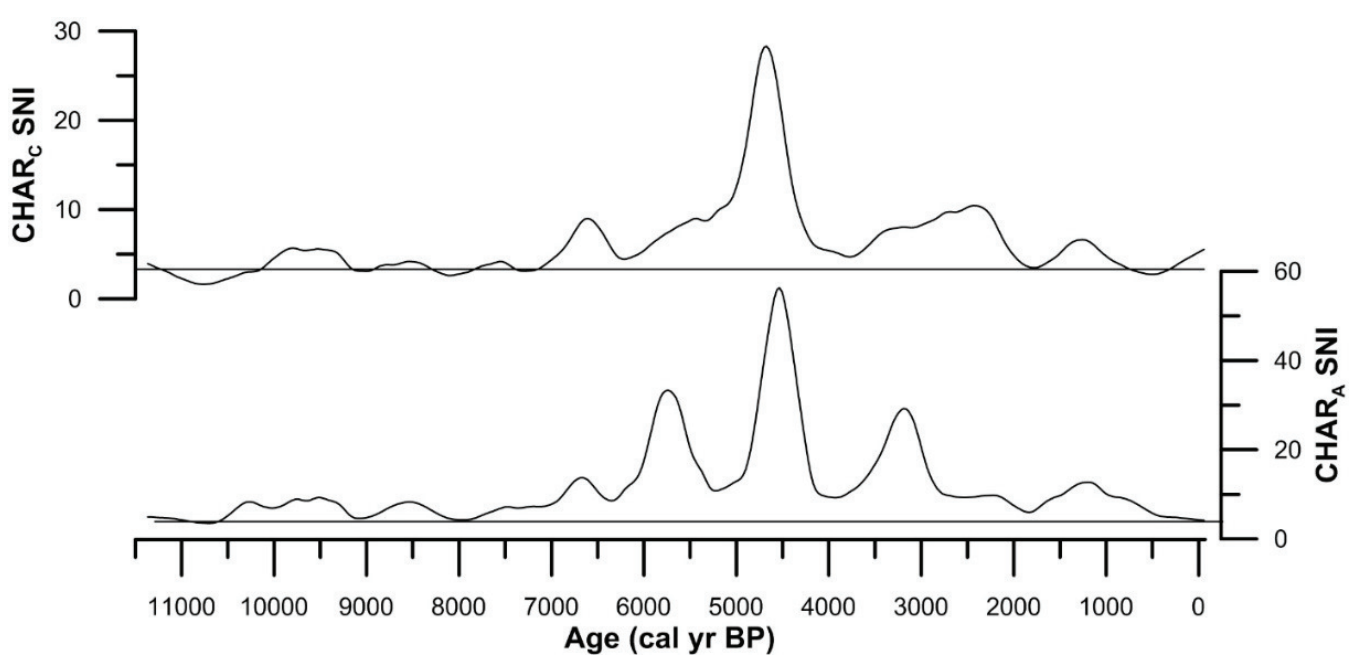

Appendix Fig. 1. Signal-to-noise (SNI) information for both $\mathrm{CHAR}_{\mathrm{C}}$ and $\mathrm{CHAR}_{\mathrm{A}}$ for Prášilské jezero. Horizontal black line indicates robust signal-to-noise index threshold level of 3.0 (Kelly et al., 2011). 


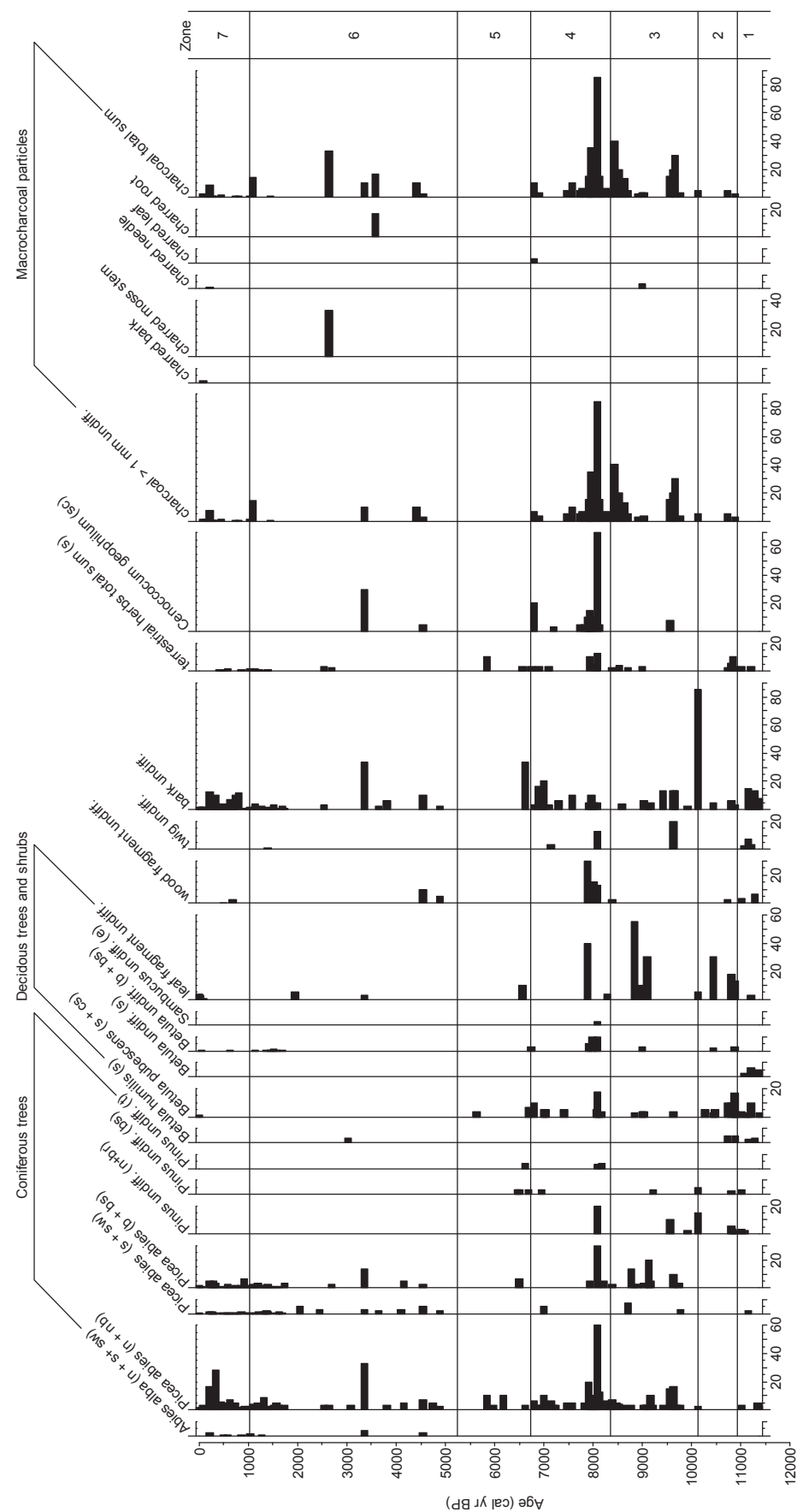

715 Appendix Fig. 2. Full macrofossil concentration diagram for Prášilské jezero. Abbreviations: $b=$

716 bud, $\mathrm{br}=$ brachyblast, $\mathrm{bs}=$ bud scale, $\mathrm{cs}=$ catkin scale, $\mathrm{e}=$ endocarp, $\mathrm{n}=$ needle, $\mathrm{nb}=$ needle

717 base, $\mathrm{s}=$ seed, $\mathrm{sc}=$ sclerotium, $\mathrm{sw}=$ seed wing, $\mathrm{t}=$ twig. Vegetation assemblage zones 


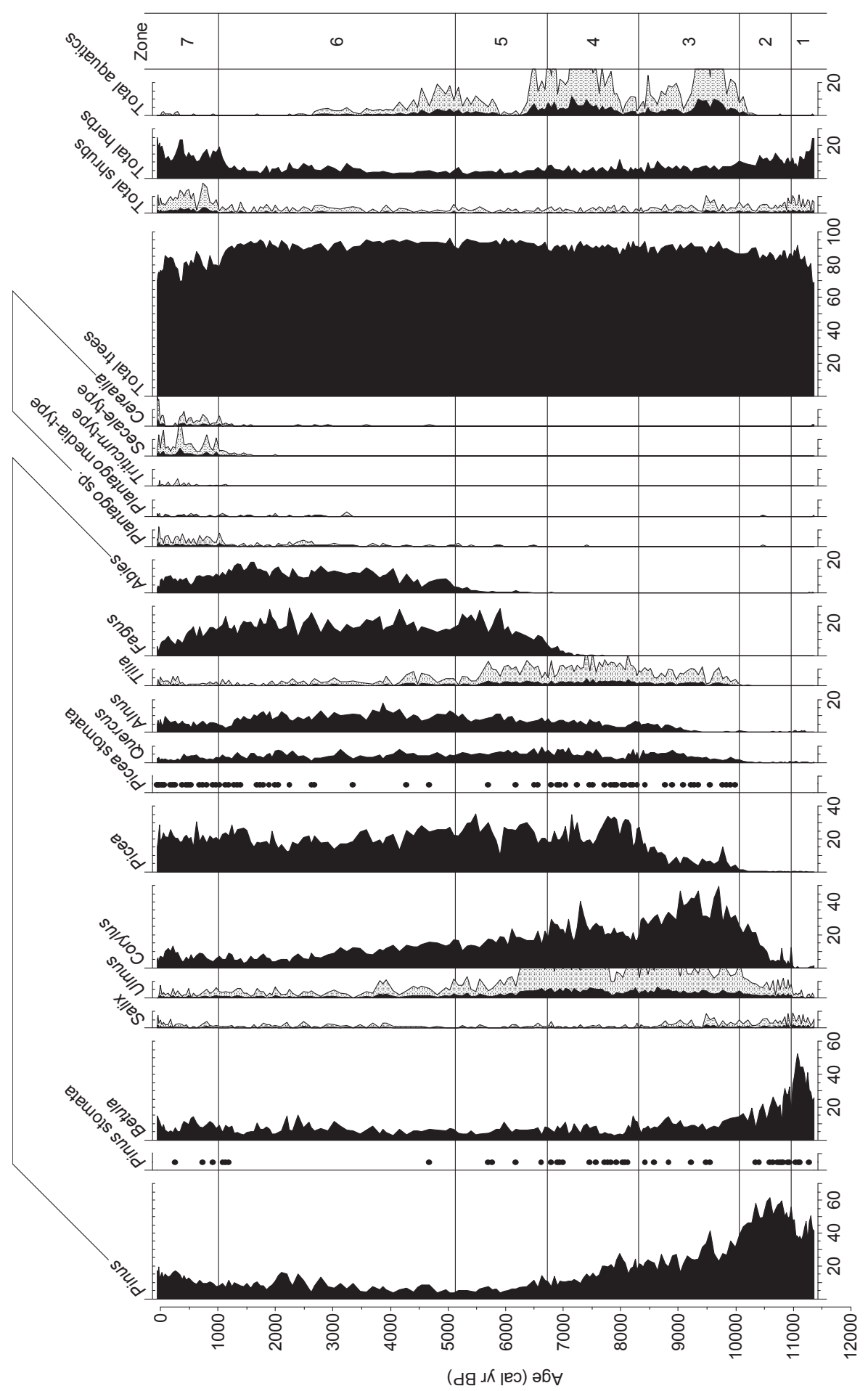


Appendix Fig. 3. Condensed pollen percentage diagram for Prášilské jezero. Pollen vegetation assemblage zones were assessed using the broken stick model (Bennett, 1996).

\begin{tabular}{|c|c|c|c|c|c|c|}
\hline $\begin{array}{l}\text { Depth below } \\
\text { water level } \\
\text { (cm) }\end{array}$ & $\begin{array}{c}\text { Core } \\
\text { ID }\end{array}$ & $\begin{array}{c}{ }^{14} \mathrm{C} \text { Age } \pm \\
2 \sigma b\end{array}$ & $\begin{array}{l}{ }^{210} \mathrm{~Pb} \text { age } \\
\text { (Year AD) }\end{array}$ & $\begin{array}{c}\text { Age (cal yr } \\
\text { BP) }\end{array}$ & $\begin{array}{c}\text { Material } \\
\text { Dated }\end{array}$ & $\begin{array}{l}\text { Lab ID } \\
\text { number }\end{array}$ \\
\hline 1480 & $\begin{array}{c}\text { PRA } 15- \\
2 \mathrm{GC}\end{array}$ & & $2015 \pm 1$ & -65 & & Surface \\
\hline 1480.5 & $\begin{array}{c}\text { PRA } 15- \\
2 \mathrm{GC}\end{array}$ & & $1995 \pm 2$ & -55 & & $\mathrm{~Pb} 210-1$ \\
\hline 1481.5 & $\begin{array}{c}\text { PRA 15- } \\
2 \mathrm{GC}\end{array}$ & & $1986 \pm 3$ & -36 & & $\mathrm{~Pb} 210-2$ \\
\hline 1482.5 & $\begin{array}{c}\text { PRA } 15- \\
2 \mathrm{GC}\end{array}$ & & $1976 \pm 4$ & -26 & & Pb210-3 \\
\hline 1483.5 & $\begin{array}{c}\text { PRA 15- } \\
\text { 2GC }\end{array}$ & & $1963 \pm 4$ & -13 & & $\mathrm{~Pb} 210-4$ \\
\hline 1484.5 & $\begin{array}{c}\text { PRA 15- } \\
\text { 2GC }\end{array}$ & & $1943 \pm 5$ & 7 & & $\mathrm{~Pb} 210-5$ \\
\hline 1485.5 & $\begin{array}{c}\text { PRA 15- } \\
2 \mathrm{GC}\end{array}$ & & $1918 \pm 7$ & 32 & & $\mathrm{~Pb} 210-6$ \\
\hline 1486.6 & $\begin{array}{c}\text { PRA } 15- \\
2 \mathrm{GC}\end{array}$ & & $1889 \pm 9$ & 61 & & $\mathrm{~Pb} 210-7$ \\
\hline
\end{tabular}




\begin{tabular}{|c|c|c|c|c|c|c|}
\hline 1487.5 & $\begin{array}{c}\text { PRA } 15- \\
2 \mathrm{GC}\end{array}$ & & $1861 \pm 12$ & 89 & & $\mathrm{~Pb} 210-8$ \\
\hline 1500.5 & $\begin{array}{c}\text { PRA } 15- \\
2-1\end{array}$ & $590 \pm 30$ & & & $\begin{array}{c}\text { Bulk } \\
\text { sediment }\end{array}$ & Poz-84783 \\
\hline 1539.2 & $\begin{array}{c}\text { PRA } 15- \\
2-1\end{array}$ & $2545 \pm 30$ & & & $\begin{array}{c}\text { Picea abies } \\
\text { needle }\end{array}$ & Poz-81580 \\
\hline 1571.75 & $\begin{array}{c}\text { PRA } 15- \\
2-2\end{array}$ & $4040 \pm 35$ & & & $\begin{array}{c}\text { Picea abies } \\
\text { needles }\end{array}$ & Poz-81582 \\
\hline 1599.75 & $\begin{array}{c}\text { PRA } 15- \\
2-2\end{array}$ & $5700 \pm 40$ & & & $\begin{array}{c}\text { Picea abies } \\
\text { needle }\end{array}$ & Poz-81583 \\
\hline 1628.5 & $\begin{array}{c}\text { PRA } 15- \\
2-1\end{array}$ & $7055 \pm 40$ & & & $\begin{array}{c}\text { Picea abies } \\
\text { needle, and } \\
\text { wood } \\
\text { fragment }\end{array}$ & Poz-87722 \\
\hline 1628.5 & $\begin{array}{c}\text { PRA } 15- \\
2-2\end{array}$ & $7550 \pm 40$ & & & $\begin{array}{c}\text { Picea abies } \\
\text { needles }\end{array}$ & Poz-80182 \\
\hline 1637 & $\begin{array}{c}\text { PRA } 15- \\
2-2\end{array}$ & $7460 \pm 40$ & & & $\begin{array}{c}\text { Picea abies } \\
\text { needles }\end{array}$ & Poz-87724 \\
\hline 1651 & $\begin{array}{c}\text { PRA } 15- \\
2-2\end{array}$ & $8210 \pm 50$ & & & $\begin{array}{l}\text { Picea abies } \\
\text { needle and } \\
\text { Picea abies } \\
\text { bud scale }\end{array}$ & Poz-84781 \\
\hline
\end{tabular}




\begin{tabular}{|c|c|c|c|c|}
\hline 1669.5 & $\begin{array}{c}\text { PRA } 15- \\
2-2\end{array}$ & $9330 \pm 60$ & $\begin{array}{l}\text { Picea abies } \\
\text { needles, } \\
\text { Betula bud } \\
\text { scales, and } \\
\text { leaf } \\
\text { fragments }\end{array}$ & Poz-81780 \\
\hline 1690.25 & $\begin{array}{c}\text { PRA } 15- \\
2-2\end{array}$ & $9620 \pm 50$ & $\begin{array}{c}\text { Picea abies } \\
\text { seed }\end{array}$ & Poz-80183 \\
\hline
\end{tabular}

Supplementary Table 1 . Summary of geochronological data $\left({ }^{14} \mathrm{C}\right.$ and ${ }^{210} \mathrm{~Pb}$ measurements $)$ for Prášilské jezero.

\section{Acknowledgements}

We would like to thank Oliver Heiri for graciously allowing us to use his stacked record of July air temperature, and acknowledge Simon Brewer for his assistance with R code used to generate the Generalized Additive Model. We want to thank John Boyle, Daniel Schillereff, Fiona Russell, Daniel Vondrák, Tereza Opravilová, and Jolana Tátosová who all helped during coring and material processing. We would also like to thank the Šumava National Forest authorities for allowing us to core Prášilské jezero. Thanks to Michal Jeníček who kindly provided the hydrometeorological data from Churáňov, purchased by Charles University. Lastly, we would like to thank the two anonymous reviewers for their comments and suggestions which greatly improved the manuscript. Datasets used in this study were obtained from the World Data Center 
for Paleoclimatology, Boulder and NOAA Paleoclimatology Program (available online at https://www.ncdc.noaa.gov/data-access/paleoclimatology-data/datasets).

Funding: This work was supported by the Czech Science Foundation [EUROPIA project no. $16-06915 \mathrm{~S}]$.

\section{References}

1. Adolf, C., Wunderle, S., Colombaroli, D., Weber, H., Gobet, E., Heiri, O., van Leeuwen, J.F.N., Bigler, C., Connor, S.E., Gałka, M., La Mantia, T., Makhortykh, S., SvitavskáSvobodová, H., Vannière, B., Tinner, W., 2017. The sedimentary and remote-sensing reflection of biomass burning in Europe. Global Ecology and Biogeography 27, 199-212. doi: $10.1111 /$ geb.12682.

2. Allen, C.D., Macalady, A.K., Chenchouni H., Bachelet, D., McDowell, N., Vennetier, M., Kitzberger, T., Rigling, A., Breshears, D. D., Hogg, E.H., Gonzalez, P., 2010. A global overview of drought and heat-inducted tree mortality reveals emerging climate change risks for forests. Forest Ecology and Management 259, 660-684, doi:10.1016/j.foreco.2009.09.001, 2010.

3. Appleby, P.G., 1978. The calculation of lead-210 dates assuming a constant rate of supply of unsupported ${ }^{210} \mathrm{~Pb}$ to the sediment. Catena $5,1-8$. doi:10.1016/S0341-8162(78)80002-2.

4. Adámek, M., Bobek, P., Hadincová, V., Wild, J., Kopecký, M., 2015. Forest fires within a temperate landscape: A decadal and millennial perspective from a sandstone region in Central Europe. Forest Ecology and Management 336, 81-90. doi:10.1016/j.foreco.2014.10.014. 
5. Ali, A.A., Higuera, P.E., Bergeron, Y., Carcaillet, C., 2009. Comparing fire-history interpretations based on area, number and estimated volume of macroscopic charcoal in lake sediments. Quaternary Research 72, 462-468. doi:10.1016/j.yqres.2009.07.002.

6. Ascoli, D., Castagneri, D., Valsecchi, C., Conedera, M., Bovio, G., 2013. Post-fire restoration of beech stands in the Southern Alps by natural regeneration. Ecological Engineering 54, 210-217. doi:10.1016/j.ecoleng.2013.01.032.

7. Beneš, J., 1996. The synantropic landscape history of the Šumava Mountains (Czech side). Silva Gabreta 1, 237-241.

8. Benito, G., Macklin, M.G., Panin, A., Rossato, S., Fontana, A., Jones, A.F., Machado, M.J., Matlakhova, E., Mozzi, P., Zielhofer, C., 2015. Recurring flood distribution patterns related to short-term Holocene climate variability. Nature Scientific Reports 5, 1-8, doi:10.1038/srep16398.

9. Bennett, K.D., 1996. Determination of the number of zones in a biostratigraphical sequence. New Phytologist 132(1), 155-170. doi:10.1111/j.1469-8137.1996.tb04521.x.

10. Berger, A., and Loutre, M.F., 1991. Insolation value for the climate of the last 10 million years. Quaternary Science Reviews 10, 297-317. doi: 10.1023/A:1006579708292.

11. Birks, H.H., 2007. Plant macrofossil introduction. In: Elias, S.A. (ed.) Encyclopedia of Quaternary Science, Volume 3. Elsevier, Amsterdam, 2266-2288.

12. Blaauw, M., and Christen, J.A., 2011. Flexible paleoclimate age-depth models using an autoregressive gamma process. Bayesian Analysis 6, 457-474. doi:10.1214/11-BA618.

13. Bobek, P., Svobodová-Svitavská, H., Werchan, B., Švarcová, M.G., Kuneš, P., 2017. Humaninduced changes in fire regime and subsequent alteration of the sandstone landscape of Northern Bohemia (Czech Republic). The Holocene, 1-17. doi:10.1177/0959683617729443. 
14. Boerner, R.E.J., 1983. Fire and nutrient cycling in Temperate Ecosystems. BioScience 32(3), 198-192. doi:10.2307/1308941.

15. Bojňanský, V., and Fargašová, A., 2007. Atlas of Seeds and Fruits of Central and EastEuropean Flora. The Carpathian Mountains Region. Springer, Dordrecht.

16. Bowman, D.M.J., Balch, J.K., Artaxo, P., Bond, W.J., Carlson, J.M., Cochrane, M.A., D’Antonio, C.M., DeFries, R.S., Doyle, J.C., Harrison, S.P., Johnston, F.H., Keeley, J.E., Krawchuk, M.A., Kull, C.A., Marston, J.B., Moritz, M.A., Prentice, I.C., Roos, C. I., Scott, A.C., Swetnam, T.W., van der Werf, G.R., Pyne, S.J., 2009. Fire in the Earth System. Science, 324, 481-484. doi: 10.1126/science.1163886.

17. Boyle, J.F., 1995. A simple closure mechanism for a compact, large-diameter, gravity corer. Journal of Paleolimnology 13(1), 85-87. doi:10.1007/BF00678113.

18. Bradshaw, R. H. W., Lindbladh, M., Hannon, G.E., 2010. The role of fire in southern Scandinavian forests during the late Holocene. International Journal of Wildland Fire 19, 1040-1049. doi: 10.1071/WF09108.

19. Brown, K.J., and Giesecke, T., 2014. Holocene fire disturbance in the boreal forest of central Sweden. Boreas 43(3), 639-651. doi: 10.1111/bor.12056.

20. Bryson, R., 2005. Archeoclimatology. Encyclopedia of World Climatology, Springer, Netherlands, p. 58-63.

21. Beug, H.-J. 2004. Leitfaden der Pollenbestimmung für Mitte leuropa und angrenzende Gebiete. Verlag Dr Friedrich Pfeil, Munich.

22. Camia, A., Liberta, G., San-Miguel-Ayanz, J., 2017. Modeling the impacts of climate change on forest fire danger in Europe. EU JRC Technical Report. pp. 1-22. doi:10.2760/768481. 
23. Cappers, R.T.J., Bekker, R.M., Jans, J.E.A., 2006. Digitale Zadenatlas van Nederland, Groningen Archaeological Studies, vol. 4. Barkhuis Publishing \& Groningen University Library, Groningen.

24. Carcaillet, C., Almquist, H., Asnong, H., Bradshaw, R.H.W., Carrión, J.S., Gaillard, M.-J., Gajewski, K., Haas, J.N., Haberle, S.G., Hadorn, P., Müller, S.D., Richard, P.J.H., Richoz, I., Rösch, M., Sánchez Goñi, M.F., von Stendingk, H., Stevenson, A.C., Talon, B., Tardy, C., Tinner, W., Tryterud, E., Wick, L., Willis, K.J., 2002. Holocene biomass burning and global dynamics of the carbon cycle. Chemosphere 49, 845-863. doi:10.1016/S00456535(02)00385-5.

25. Carcaillet, C., Bergman, I., Delorme, S., Hornberg, G., Zackrisson, O., 2007. Long-term fire frequency not linked to prehistoric occupation in northern Swedish boreal forest. Ecology 88, 465-477. doi:10.1890/0012-9658(2007)88[465:LFFNLT]2.0.CO;2.

26. Carter, V.A., Chiverrell, R.C., Clear, J.L., Kuosmanen, N., Moravcová, A., Svoboda, M., Svobodová-Svitavská, H., van Leeuwen, J.F.N., van der Knaap, W.O., Kuneš, P., 2018. Quantitative palynology informing conservation ecology in the Bohemian/Bavarian Forests of Central Europe. Frontiers in Plant Science 8, 1-14. doi:10.3389/fpls.2017.02268.

27. Colombaroli, D., Henne, P.D., Kaltenrieder, P., Gobet, E., Tinner, W., 2010. Species responses to fire, climate and human impact at tree line in the Alps as evidenced by palaeoenvironmental records and a dynamic simulation model. Journal of Ecology 98, 1346-1357. doi: 10.1111/j.1365-2745.2010.01723.x.

28. Cheddadi, R., Araújo, M.B., Maiorano, L., Edwards, M., Guisan, A., Carré, M., Chevalier, M., Pearman, P.B., 2016. Temperature range shifts for three European tree species over the last 10,000 years. Frontiers in Plant Science 7, 1-13. doi:10.3389/fpls.2016.01581. 
29. Christensen, J.H., B. Hewitson, A. Busuioc, A. Chen, X. Gao, I. Held, R. Jones, R.K. Kolli, W.-T. Kwon, R. Laprise, V. Magaña Rueda, L. Mearns, C.G. Menéndez, J. Räisänen, A. Rinke, A. Sarr and P. Whetton, 2007: Regional Climate Projections. In: Climate Change 2007: The Physical Science Basis. Contribution of Working Group I to the Fourth Assessment Report of the Intergovernmental Panel on Climate Change [Solomon, S., D. Qin, M. Manning, Z. Chen, M. Marquis, K.B. Averyt, M. Tignor and H.L. Miller (eds.)]. Cambridge University Press, Cambridge, United Kingdom and New York, NY, USA.

30. Clark, J.S., 1988. Particle motion and the theory of charcoal analysis: source area, transport, deposition, and sampling. Quaternary Research, 30, 67-80. doi: 10.1016/00335894(88)90088-9.

31. Clark, J.S., Merkt, J., Müller, H., 1989. Post-glacial fire, vegetation, and human history on the Northern Alpine Forelands, southwestern Germany. Journal of Ecology 77, 897-925. DOI: $10.2307 / 2260813$.

32. Clear, J.L., Seppä, H., Kuosmanen, N., Bradshaw, R.H.W., 2015. Holocene stand-scale vegetation dynamics and fire history of an old-growth spruce forest in southern Finland. Vegetation History Archaeobotany 24, 731-741. doi:10.1007/s00334-015-0533-z.

33. Courtney-Mustaphi, C.J, and Pisaric, M.F.J., 2013. Varying influence of climate and aspect as controls of montane forest fire regimes during the late Holocene, south-eastern British Columbia, Canada. Journal of Biogeography 40, 1983-1996. doi:10.1111/jbi.12143.

34. Čuláková, K., Eigner, J., Fröhlich, J., Metlička, M., Řezáč, M., 2012a: Horské laténské sídliště na Šumavě. Prášily - Sklářské údolí, okr. Klatovy [Eine Latènezeitliche Bergsiedlung im Böhmerwald. Prášily - Sklářské údolí, Kr. Klatovy]. Archeologické výzkumy v jižních Čechách $25,97-115$. 
35. Čuláková, K., Eigner, J., Fröhlich, J., Metlička, M., Řezáč, M., 2012b. Horské laténské sídliště na Šumavě. Prášily - Sklářské údolí, okr. Klatovy. Archeology výzkumy v jižních Čechách $25,97-117$.

36. Daniau, A.L., Bartlein, P.J., Harrison, S.P., Prentice, I.C., Brewer, S., Friedlingstein, P., Harrison-Prentice, T.I. , Inoue, J., Marlon, J.R., Mooney, S., Power, M.J., Stevenson, J., Tinner, W., Andric, M., Atanassova, J., Behling, H., Black, M., Blarquez, O., Brown, K.J., Carcaillet, C., Colhoun, E.A., Colombaroli, D., Davis, B.A.S., D’Costa, D., Dodson, J., Dupont, L., Eshetu, A., Gavin, D.G., Genries, A., Gebru, T., Haberle, S., Hallett, D.J., Horn, S., Hope, G., Katamura. F., Kennedy, L., Kershaw, P., Krivonogov, S., Long, C., Magri, D., Marinova, E., McKenzie, G.M., Moreno, P.I., Moss, P., Neumann, F.H., Norström, E., Paitre, C., Rius, D., Roberts, N., Robinson, G., Sasaki, N., Scott, L., Takahara, H., Terwilliger, V., Thevenon, F., Turner, R.B., Valsecchi, V.G., Vannière, B., Walsh, M., Williams, N., Zhang, Y., 2012. Predictability of biomass burning in response to climate changes. Global Biogeochemical Cycles 26, GB4007. doi:10.1029/2011GB004249.

37. Davis, B.A.S., Brewer, S., Stevenson, A.C., Guiot, J., 2003. The temperature of Europe during the Holocene reconstructed from pollen data. Quaternary Science Reviews 22, 17011716. doi:10.1016/S0277-3791(03)00173-2.

38. Delarze, R., Calderari, D., Hainard, P., 1992. Effects of fire on forest dynamics in southern Switzerland. Journal of Vegetation Science 3, 55-60. doi:10.2307/3235998.

39. Delcourt, P.A., and Delcourt, H.R., 1987. Long-term forest dynamics of the temperate zone: A case study of late-Quaternary forests in eastern North America. New York: Springer. 
40. Divišová, M. and Šída, P. 2015. Plant use in the Mesolithic period: archaeobotanical data from the Czech Republic in a European context: a review. Interdisciplinaria archaeologica: natural sciences in archaeology, 6, 95-106.

41. Dreslerová, D., 2012. Human Response to Potential Robust Climate Change around 5500 cal BP in the Territory of Bohemia (the Czech Republic). Interdisciplinaria Archaeologica Natural Sciences in Archaeology 3, 43-55.

42. Dreslerová, D., 2016. 'Salaš': summer farming and transhumance in the Czech Republic from a (pre)historic, and environmental perspective. In: Collis, J., Mark Pearce, M., Nicolis, F. (eds.): Summer farms. Seasonal exploitation of the uplands from prehistory to the present. Sheffield Archaeological Monographs 16 J.R. Collis Publications, Sheffield.

43. Eigner, J., Kapustka, K., Parkman, M., Řezáč, M., 2017. Mezolitické osídlení Šumavy podledem studia surovin kamenných artefaktů z lokalit Javoží Pila 1 a Nová Pec. Silva Gabreta 23, 33-44.

44. Ellenberg, H., 1982. Vegetation Mitteleuropas mit den Alpen in ökologischer Sicht. Eugen Ulmer GmbH, Stuttgart.

45. Engelmark, O., Kullman, L., Bergeron, Y., 1994. Fire and age structure of Scots pine and Norway spruce in northern Sweden during the past 700 years. New Phytologist 126, $163-$ 168. doi:10.1111/j.1469-8137.1994.tb07542.x.

46. Faegri, K., Kaland, P.E., Krzywinski, K., 1989. Textbook of Pollen Analysis. Wiley, New York.

47. Falk, D.A., Heyerdahl, E.K., Brown, P.M., Farris, C., Fulé, P.Z., McKenzie, D., Swetnam, T.W., Taylor, A.H., Van Horne, M.L., 2011. Multi-scale controls of historical forest-fire 
regimes: new insights from fire-scar networks. Frontiers in Ecology and the Environment 9(8), 446-454. doi:10.1890/100052.

48. Fernandes, P.M., 2009. Combining forest structure data and fuel modelling to assess fire hazard in Portugal. Annals of Forest Science 66, 415-419. doi:10.1051/forest/2009013.

49. Feurdean, A., Spessa, A., Magyari, E.K., Willis, K.J., Veres, D., Hickler, T., 2012. Trends in biomass burning in the Carpathian region over the past 15,000 years. Quaternary Science Reviews 45, 111-125. doi:10.1016/j.quascirev.2012.04.001.

50. Feurdean, A., Liakka, J., Vannière, B., Marinova, E., Hutchinson, S.M., Mosburgger, V., Hickler, T., 2013. 12,000-Years of fire regime drivers in the lowlands of Transylvania (Central-Eastern Europe): a data-model approach. Quaternary Science Reviews 81, 48-61. doi:10.1016/j.quascirev.2013.09.014.

51. Feurdean, A., Florescu, G., Vannière, B., Tanțău, I., O’Hara, R.B., Pfeiffer, M., Hutchinson, S.M., Galka, M., Moskal-del Hoyo, M., Hickler, T., 2017. Fire has been an important driver of forest dynamics in the Carpathian Mountains during the Holocene. Forest Ecology Management 389, 15-26. doi:10.1016/j.foreco.2016.11.046.

52. Feurdean, A., and Vannière, B., 2017. Natural and human-driven fire regime and land-cover changes in Central and Eastern Europe. Workshop Report, PAGES Magazine 25(2), 115. doi:10.22498/pages.25.2.115.

53. Feyen, L., and Dankers, R., 2009. Impact of global warming on streamflow drought in Europe. Journal of Geophysical Research 114:D17116. doi: 10.1029/2008JD011438.

54. Finsinger, W. and Tinner, W., 2005. Minimum count sums for charcoal-concentration estimates in pollen slides: Reliability and potential errors. The Holocene 15: 293-297. doi:10.1191/0959683605h1808rr. 
55. Finsinger, W, Tinner, W., van der Knaap, W.O., Ammann, B., 2006. The expansion of hazel (Corylus avellana L.) in the southern Alps: a key for understanding its early Holocene history in Europe? Quaternary Science Reviews 25, 612-631. doi:10.1016/j.quascirev.2005.05.006.

56. Finsinger, W., Kelly, R., Fevre, J., Magyari, E.K., 2014. A guide to screening charcoal peaks in macrocharcoal-area records for fire-episode reconstructions. The Holocene 24(8), 10021008. doi:10.1177/0959683614534737.

57. Finsinger, W., Fevre, J., Orbán, I., Pál, I., Vincze, I., Hubay, K., Birks, H.H., Braun, M., Tóth, M., Magyari, E.K., 2016. Holocene fire-regime changes near the treeline in the Retezat Mts. (Southern Carpathians, Romania). Quaternary International in press, doi:10.1016/j.quaint.2016.04.029.

58. Fohlmeister, J., Vollweiler, N., Spötl, C., Mangini, A., 2013. COMNISPA II: Update of a mid-European isotope climate record, 11 ka to present. The Holocene 23(5), 749-754. doi: 10.1177/0959683612465446.

59. Fröhlich, J., 2009. Pravěké osídlení v horských a dalších vysokých polohách v jižních Čechách. (Prehistoric settlement in the mountainous and higher-altitude locations of southern Bohemia). Časopis Společnosti přátel starožitností 117, 150-156.

60. Gao, X., and Giorgi, F., 2008. Increased aridity in the Mediterranean region under greenhouse gas forcing estimated from high resolution simulations with a regional climate model. Global Planetary Change 62, 195-209. doi: 10.1016/j.gloplacha.2008.02.002.

61. Gavin, D.G., Brubaker, L.B., Lertzman, K.P., 2003. Holocene fire history of a coastal temperate rain forest based on soil charcoal radiocarbon dates. Ecology 84, 186-201. doi:10.1890/0012-9658(2003)084[0186:HFHOAC]2.0.CO;2. 
62. Gavin, D.G., Hu, F.S., Lertzman, K., Corbett, P., 2006. Weak climatic control of standscale fire history during the late Holocene. Ecology 87, 1722-1732. doi:10.1890/00129658(2006)87[1722:WCCOSF]2.0.CO;2.

63. Gedalof, Z., 2011. Climate and spatial patterns of wildfire. The landscape ecology of fire (ed. by D. McKenzie, C. Miller and D. Falk), Springer, Dordrecht. pp. 89-115.

64. Giesecke, T., Hickler, T., Kunkel, T., Sykes, M.T., Bradshaw, R.H.W., 2007. Towards an understanding of the Holocene distribution of Fagus sylvatica L. Journal of Biogeography 34, 118-131. doi:10.1111/j.1365-2699.2006.01580.x.

65. Giesecke, T, Brewer, S., Finsinger, W., Leydet, M., Bradshaw, R.H.W., 2017. Patterns and dynamics of European vegetation change over the last 15,000 years. Journal of Biogeography 44, 1441-1456. doi:10.1111/jbi.12974.

66. Gottfried, M., Pauli, H., Futschik, A., Akhalkatsi, M., Barančok, P., Benito Alonso, J.L., Coldea, G., Dick, J., Erschbamer, B., Fernández Calzado, M.R., Kazakis, G., Krajči, J., Larsson, P., Mallaun, M., Michelsen, O., Moiseev, D., Moiseev, P., Molau, U., Merzouki, A., Nagy, L., Nakhutsrishvili, G., Pedersen, B., Pelino, G., Puscas, M., Rossi, G., Stanisci, A., Theurillat, J.-P., Tomaselli, M., Villar, L., Vittoz, P., Vogiatzakis, I., Grabherr, G., 2012. Continent-wide response of mountain vegetation to climate change. Nature Climate Change 2, 111-115. doi:10.1038/nclimate1329.

67. Grimm, E., 2004 Tilia Software version 2.0.41 (Computer Software). Springfield, Illinois State Museum, Research and Collections Center.

68. Hanewinkel, M., Cullmann, D. A., Schelhaas, M.-J., Nabuurs, G.J., and Zimmermann, K. E., 2012. Climate change may cause severe loss in the economic value of European forest land. Nature Climate Change 3, 203-207. doi: 10.1038/nclimate1687. 
69. Hastie, T.J. and Tibshirani, R.J., 1986. Generalized Additive Models. Statistical Science 1(3), 297-318.

70. Heiri, O. and Lotter, A.F., 2001. Effect of low count sums on quantitative environmental reconstructions: An example using subfossil chironomids. Journal of Paleolimnology 26, 343 350. doi:10.1023/A:1017568913302.

71. Heiri, O., Lotter, A.F., Hausmann, S., Kienast F., 2003. A chironomid-based Holocene summer air temperature reconstruction from the Swiss Alps. The Holocene 13, 477-484. doi:10.1191/0959683603hl640ft.

72. Heiri, O., Ilyashuk, B., Millet, L., Samartin, S., Lotter, A.F., 2015. Stacking of discontinuous regional paleoclimate records: Chironomid-based summer temperatures from the Alpine region. The Holocene 25(1), 137-149. doi:10.1177/0959683614556382.

73. Higgins, P., and MacFadden, B.J., 2009. Seasonal and geographic climate variabilities during the Last Glacial Maximum in North America: Applying isotopic analysis and macrophysical climate models. Palaeogeography Palaeoclimatology Palaeoecology, 283, 15-27. doi:10.1016/j.palaeo.2009.08.015.

74. Higuera, P.E., Peters, M.E., Brubaker, L.B., Gavin, D.G., 2007. Understanding the origin and analysis of sediment-charcoal records with a simulation model. Quaternary Science Reviews 26, 1790-1809. doi:10.1016/ J.QUASCIREV.2007.03.010.

75. Higuera, P.E., Brubaker, L.B., Anderson, P.M., Hu, F.S., Brown, T.A., 2009. Vegetation mediated the impacts of postglacial climate change on fire regimes in the south-central Brooks Range, Alaska. Ecological Monographs 79, 201-219. doi:10.1890/07-2019.1. 
76. Higuera, P.E., Gavin, D.G., Bartlein, P.J., Hallet, D.J., 2010. Peak detection in sedimentcharcoal records: impacts of alternative data analysis methods on fire-history interpretation. International Journal of Wildland Fire, 19, 996-1014. doi:10.1071/WF09134.

77. Huntley, B., 1993. Rapid early-Holocene migration and high abundance of hazel (Corylus avellana L.): alternative hypotheses, in: Chambers, F.M. (Ed.), Climate Change and Human Impact on the Landscape. Chapman \& Hall, London, pp. 205-215.

78. Jamrichová, E., Potůčková, A., Horsák, M., Hajnalová, M., Barta, P., Tóth, P., Kuneš, P., 2014. Early occurrence of temperate oak-dominated forest in the northern part of the Little Hungarian Plain, SW Slovakia. The Holocene 24, 1810-1824. doi:10.1177/0959683614551225.

79. Kaplan, J.O., Pfeiffer, M., Kolen, J.C.A., Davis, B.A.S., 2016. Large Scale Anthropogenic Reduction of Forest Cover in Last Glacial Maximum Europe. PLoS ONE 11(11), e0166726. doi:10.1371/journal.pone.0166726.

80. Keeley, J.E., 2009. Fire intensity, fire severity and burn severity: a brief review and suggested usage. International Journal of Wildland Fire 18, 116-126. doi:10.1071/WF07049.

81. Kuneš, P., Svobodová-Svitavská, H., Kolář, J., Hajnalová, M., Abraham, V., Macek, M., Tkáč, P., Szabó, P., 2015. The origin of grasslands in the temperate forest zone of eastcentral Europe: long-term legacy of climate and human impact. Quaternary Science Reviews 116, 15-27. doi:10.1016/j.quascirev.2015.03.014.

82. Katz, N.J., Katz, S.V., Skobeeva, E.I., 1977. Atlas of Plant Remains in Peat. Nedra, Moscow.

83. Kelly, R., Higuera, P.E., Barrett, C.M., Hu, F.S., 2011. A signal-to-noise index to quantify the potential for peak detection in sediment-charcoal records. Quaternary Research, 75, 11-17. doi:10.1016/j.yqres.2010.07.011. 
84. Killick, R., and Eckley, I.A., 2014. Change point: an R Package for Change point Analysis. Journal of Statistical Software 58(3). doi: 10.18637/jss.v058.i03.

85. Lavalle, C., Micale, F., Houston, T.D., Camia, A., Hiederer, R., Lazar, C., Conte, C., Amatulli, G., Genovese, G., 2009. Climate change in Europe. 3. Impact on agriculture and forestry. A review. Agronomy for Sustainable Development 29, 433-446. doi:10.1051/agro/2008068.

86. Linder, M., Fitzgerald, J.B., Zimmermann, N., Reyer, C., Delzon, S., van der Maaten, E., Schelhaas, M-J., Lasch, P., Eggers, J., van der Maaten-Theunissen, M., Suckow, F., Psomas, A., Poulter, B., Hanewinkel, M., 2014. Climate Change and European forests: What do we know, what are the uncertainties, and what are the implications for forest management? Journal of Environmental Management 146, 69-83. doi:10.1016/j.jenvman.2014.07.030.

87. Litt, T., Scholzel, C., Kuhl, N., Brauer, A., 2009. Vegetation and climate history in the Westeifel volcanic field (Germany) during the past 11,000 years based on annually laminated lacustrine maar sediments. Boreas 38, 679-690. doi:10.1111/j.1502-3885.2009.00096.x.

88. Lung, T., Lavelle, C., Hiederer, R., Dosio, A., Bouwer, L.M., 2013. A multi-hazard regional level impact assessment for Europe combining indicators of climatic and non-climatic change. Global Environmental Change 23, 522-536. doi:10.1016/j.gloenvcha.2012.11.009.

89. MacDonald, G.M., Larsen, C.P.S., Szcicz, J.M., Moser, K.A., 1991. The reconstruction of boreal forest fire history from lake sediments: a comparison of charcoal, pollen, sedimentological, and geochemical indices. Quaternary Science Reviews 10, 53-71. doi:10.1016/0277-3791(91)90030-X.

90. Maher, L.J., 1972. Nomograms for counting 0.95 confidence limits of pollen data. Review of Palaeobotany and Palynology 13, 85-93. 
91. Maher, L.J., Heiri, O., and Lotter, A.F., 2012. Assessment of uncertainties associated with palaeolimnological laboratory methods and microfossil analysis, in: Birks, H.J.B., Lotter, A.F., Juggins, S., Smol, J.P. (Eds). Tracking Environmental Change Using Lake Sediments, Vol. 5: Data Handling and Numerical Techniques. Springer, Dordrecht, pp. 143-166.

92. Marlon, J.R., Bartlein, P.J., Daniau, A-L., Harrison, S.P., Maezumi, S.Y., Power, M.J., Tinner, W., Vannière, B., 2013. Global biomass burning: a synthesis and review of Holocene paleofire records and their controls. Quaternary Science Reviews 65, 5-25. doi:10.1016/j.quascirev.2012.11.029.

93. Mauri, A., Davis, B.A.S., Collins, P.M., Kaplan, J.O., 2015. The Climate of Europe during the Holocene: a gridded pollen-based reconstruction and its multiproxy evaluation, Quaternary Science Reviews 112, 109-127. doi:10.1016/j.quascirev.2015.01.013.

94. Mentlík, P., Minár, J., Břízová, E., Lisá, L., Tábořík, P., Stacke, V., 2010. Glaciation in the surroundings of Prásilské Lake (Bohemian Forest, Czech Republic). Geomorphology 117, $181-194$

95. Minckley, T.A., and Long, C.J., 2016. Paleofire severity and vegetation change in the Cascade Range, Oregon, USA. Quaternary Research 85, 211-217. doi:10.1016/j.yqres.2015.12.010.

96. Mooney, S.D. and Tinner, W., 2011. The analysis of charcoal in peat and organic sediments. Mires and Peat 7, 1-18.

97. Niklasson, M. and Granström, A., 2000. Numbers and sizes of fires: long-term spatially explicit fire history in a Swedish boreal landscape. Ecology 81, 1484-1499. doi:10.1890/0012-9658(2000)081[1484:NASOFL]2.0.CO;2. 
98. Niklasson, M., 2002. A comparison of three age determination methods for suppressed Norway spruce: implication for age structure analysis. Forest Ecology and Management 161, 279-288. Doi:10.1016/S0378-1127(01)00500-X.

99. Niklasson, M., Zin, E., Zielonka, T., Feijen, M., Korczyk, A.F., Churski, M., Samojlik, T., Jędrzejewska, B., Gutowski, J.M., Brzeziecki, B., 2010. A 350-year tree-ring fire record from Białowieża Primeval Forest, Poland: implications for Central European lowland fire history. Journal of Ecology 98, 1319-1329. doi:10.1111/j.1365-2745.2010.01710.x.

100. Novák, J., Sádlo, J., Svobodová-Svitavská, H., 2012. Unusual vegetation stability in a lowland pine forest area (Doksy region, Czech Republic). The Holocene 22, 947-955. doi:10.1177/0959683611434219.

101. Ohlson, M., Brown, K.J., Birks, H.J.B., Grytnes, J-A., Hörnberg, G., Niklasson, M., Seppä, H., Bradshaw, R.H.W., 2011. Invasion of Norway spruce diversifies the fire regime in boreal European forests. Journal of Ecology 99, 395-403. doi:10.1111/j.13652745.2010.01780.x.

102. Pelc, Z. and Šebesta, J., 1994: Geologická mapa ČR. List 22-33 Kašperské Hory. 1:50,000. Český geologický ústav Praha.

103. Per $\square$ oiu, A., Onac, B.P., Wynn, J.G., Blaauw, M., Ionita, M., Hansson, M., 2017. Holocene winter climate variability in Central and Eastern Europe. Nature 7, 1-8. doi:10.1038/s41598-017-01397-w.

104. Power, M.J., Marlon, J., Ortiz, N., Bartlein, P.J., Harrison, S.P., Mayle, F.E., Ballouche, A., Bradshaw, R.H.W., Carcaillet, C., Cordova, C., Mooney, S., Moreno, P.I., Prentice, I.C., Thonicke, K., Tinner, W., Whitlock, C., Zhang, Y., Zhao, Y., Ali, A.A., Anderson, R.S., Beer, R., Behling, H., Briles, C., Brown, K.J., Brunelle, A., Bush, M., Camill, P., Chu, G.Q., Clark, 
J., Colombaroli, D., Connor, S., Daniau, A.-L., Daniels, M., Dodson, J., Doughty, E., Edwards, M.E., Finsinger, W., Foster, D., Frechette, J., Gaillard, M.-J., Gavin, D.G., Gobet, E., Haberle, S., Hallett, D.J., Higuera, P., Hope, G., Horn, S., Inoue, J., Kaltenrieder, P., Kennedy, L., Kong, Z.C., Larsen, C., Long, C.J., Lynch, J., Lynch, E.A., McGlone, M., Meeks, S., Mensing, S., Meyer, G., Minckley, T., Mohr, J., Nelson, D.M., New, J., Newnham, R., Noti, R., Oswald, W., Pierce, J., Richard, P.J.H., Rowe, C., Sanchez Goñi, M.F., Shuman, B.N., Takahara, H., Toney, J., Turney, C., Urrego-Sanchez, D.H., Umbanhowar, C., Vandergoes, M., Vannière, B., Vescovi, E., Walsh, M., Wang, X., Williams, N., Wilmshurst, J., Zhang, J.H., 2008. Changes in fire regimes since the Last Glacial Maximum: an assessment based on a global synthesis and analysis of charcoal data. Climate Dynamics 30, 887-907. doi:10.1007/s00382007-0334-x.

105. Punt, W. 1976-1996. The northwest European pollen flora 1-7. Elsevier, Amsterdam.

106. R Core Development Team, 2012. R: a Language and Environment for Statistical Computing, Reference Index Version 2.14. R Foundation for Statistical Computing, Vienna, Austria.

107. Reimer, P.J., Bard, E., Bayliss, A., Beck, J.W., Blackwell, P.G., Ramsey, C.B., Buck, C.E., Cheng, H., Edwards, R.L., Friedrich, M., Grootes, P.M., Guilderson, T.P., Haflidason, H., Hajdas, I., Hatté, C., Heaton, T.J., Hoffmann, D.L., Hogg, A.G., Hughen, K.A., Kaiser, K.F., Kromer, B., Manning, S.W., Niu, M., Reimer, R.W., Richards, D.A., Scott, E.M., Southon, J.R., Staff, R.A., Turney, C.S.M., van der Plicht, J., 2013. IntCal13 and Marine13 radiocarbon age calibration curves 0-50,000 years cal BP. Radiocarbon 55(4), 1869-1887. doi:10.2458/azu_js_rc.55.16947. 
108. Rejczak, J., Pall, P., Schär, C., 2013. Projections of extreme precipitation events in regional climate simulations for Europe and the Alpine Region. Journal of Geophysical Research 118(9), 3610-3626. doi:10.1002/jgrd.50297,

109. Riehl, S., Pustovoytov, K.E., Hotchkiss, S., Bryson, R.A., 2009. Local Holocene environmental indicators in Upper Mesopotamia: Pedogenic carbonate record vs. archaeobotanical data and archaeoclimatological models. Quaternary International 209, 154 162. doi:10.1016/j.quaint.2008.06.012.

110. Robichaud, P.R., 2000. Fire effects on infiltration rates after prescribed fire in Northern Rocky Mountain forests, USA. Journal of Hydrology 231, 220-229. doi:10.1016/S00221694(00)00196-7.

111. Seneviratne, S.I., N. Nicholls, D. Easterling, C.M. Goodess, S. Kanae, J. Kossin, Y. Luo, J. Marengo, K. McInnes, M. Rahimi, M. Reichstein, A. Sorteberg, C. Vera, and X. Zhang, 2012: Changes in climate extremes and their impacts on the natural physical environment. In: Managing the Risks of Extreme Events and Disasters to Advance Climate Change Adaptation [Field, C.B., V. Barros, T.F. Stocker, D. Qin, D.J. Dokken, K.L. Ebi, M.D. Mastrandrea, K.J. Mach, G.-K. Plattner, S.K. Allen, M. Tignor, and P.M. Midgley (eds.)]. A Special Report of Working Groups I and II of the Intergovernmental Panel on Climate Change (IPCC). Cambridge University Press, Cambridge, UK, and New York, NY, USA, pp. 109-230.

112. Š́́ída P., Eigner J., Fröhlich J., Moravcová M. \& Franzeová D., 2011: Doba kamenná v povodí horní Otavy [Stone Age of the Upper Otava River region]. Archeologické výzkumy v jižních Čechách - Supplementum 7, České Budějovice-Plzeň, 184 pp.

113. Sommer, C. S., ed., 2006, Archäologie in Bayern: Fenster zur Vergangenheit. Regensburg. 
114. Stockmarr, J., 1972. Tablets with spores used in absolute pollen analysis. Pollen and Spores $13,614-621$.

115. Tinner, W., Conedera, M., Ammann, B., Gaggcler, H.W., Gedye, S., Junes, R., Sagesscr, B., 1998. Pollen and charcoal in lake sediments compared with historically documented forest fires in southern Switzerland since AD 1920. The Holocene 8, 31-42. doi:10.1191/095968398667205430.

116. Tinner, W., Hubschmid, P., Wehrli, M., Ammann, B., Conedera, M., 1999. Long-term fire ecology and dynamics in southern Switzerland. Journal of Ecology 87, 273-289. doi:10.1046/j.1365-2745.1999.00346.x.

117. Tinner, W., Conedera, M., Gobet, E., Hubschmid, P., Wehrli, M., Ammann, B., 2000. A palaeoecological attempt to classify fire sensitivity of trees in the southern Alps. The Holocene 10, 565-574. doi:10.1191/095968300674242447.

118. Tinner, W. and Hu, F.S., 2003. Size parameters, size-class distribution and area-number relationship of microscopic charcoal: Relevance for fire reconstruction. The Holocene 13, 499505. doi:10.1191/0959683603hl615rp.

119. Tomlinson, P., 1985. An aid to the identification of fossil buds, bud-scales and catkinbracts of British trees and shrubs. Circaea 3, 45-130.

120. Valese, E., Conedera, M., Held, A.C., Ascoli, D., 2014. Fire, humans and landscape in the European Alpine region during the Holocene. Anthropocene 6, 63-74. doi:10.1016/j.ancene.2014.06.006.

121. Vannière, B., Blarquez, O., Rius, D., Doyen, E., Brücher, T., Colomaroli, D., Connor, S., Feurdean, A., Hickler, T., Kaltenrieder, P., Lemmen, C., Leys, B., Massa, C., Olofsson, J., 
2016. 7000-year human legacy of elevation-dependent European fire regimes. Quaternary Science Reviews 132, 206-212. doi:10.1016/j.quascirev.2015.11.012.

122. Vencl S. (ed.), Fröhlich J., Horáček I., Michálek J., Pokorný P.,Přichystal A., 2006. Nejstarší osídlení jižních Čech. Paleolit a mesolit [The earliest settlement of South Bohemia. Palaeolithic and Mesolithic]. Institute of Archaeology CAS, Prague, 475 pp.

123. Vrba, J., Kopáček, J., Straškrabová, V., Hejzlar, J., Šimek, K., 1996. Limnological research of acidified lakes in Czech part of the Šumava Mountains: trophic status and dominance of microbial food webs. Silva Gabreta 1, 151-164.

124. Vrba, J., Kopáček, J., and Fott, J., 2000. Long-term limnological research of the Bohemian Forest lakes and their recent status. Silva Gabreta 4, 7-28.

125. Whitlock, C., and Larsen, C., 2001. Charcoal as a fire proxy, in: Smol, J.P., Birks, H.J.B., Last, W.M. (Eds.), Tracking Environmental Change Using Lake Sediments. Springer, Dordrecht, 75-97.

126. Whitlock, C., Shafer, S.L., Marlon, J., 2003. The role of climate and vegetation change in shaping past and future fire regimes in the northwestern US and the implications for ecosystem management. Forest Ecology and Management 178, 5-21. doi:10.1016/S03781127(03)00051-3.

127. Whitlock, C., Higuera, P.E., McWethy, D.B., Briles, C.E., 2010. Paleoecological perspectives on fire ecology: revisiting the fire-regime concept. The Open Ecology Journal, 3, 6-23. doi:10.2174/1874213001003020006.

128. Wood, S.N., 2006. Generalized Additive Models: an introduction with R. Boca Raton: CRC/Chapman \& Hall 
1163 129. Xanthopoulos, G., Calfapietra, C., Fernandes, P., 2012. Fire Hazard and Flammability of 1164 European Forest Types, in: Moreira, F., Arianoutsou, M., Corona, P., De las Heras, J. (Eds.), 1165 Post-Fire Management and Restoration of Southern European Forests, Managing Forest Ecosystems, vol 24. Springer, Dordrecht, 79-92.

1167 130. Zackrisson, O., 1977. Influence of forest fires on north Swedish boreal forest. Oikos 29, 1168 $22-32$. 